\title{
Iron Age peat cutting and ritual depositions in bogs - new evidence from Fuglsøgaard Mose, Denmark
}

\author{
Morten Fischer Mortensen ${ }^{1,6}$, Charlie Christensen ${ }^{1}$, Karin Johannesen ${ }^{2}$, Ernst Stidsing ${ }^{3}$, \\ Reno Fiedel ${ }^{4}$ and Jesper Olsen ${ }^{5}$ \\ ${ }^{1}$ The National Museum of Denmark, Environmental Archaeology and Materials Science, I.C. Modewegsvej, \\ 2800 Kgs. Lyngby, Denmark \\ ${ }^{2}$ Nordjyllands Historiske Museum, Algade 48, 8000 Aalborg, Denmark \\ ${ }^{3}$ Museum Østjylland, Stemannsgade 2, 8900 Randers, Denmark \\ ${ }^{4}$ Independent researcher \\ ${ }^{5} \mathrm{AMS}{ }^{14} \mathrm{C}$ Dating Centre, Department of Physics and Astronomy, University of Aarhus, Ny Munkegade 120, \\ 8000 Aarhus C, Denmark \\ ${ }^{6}$ Corresponding author (morten.fischer.mortensen@natmus.dk) ORCID: 0000-0002-4167-8227
}

\begin{abstract}
With the discovery of peat and gyttja deposits containing archaeological remains, sealed below a colluvium, at Fuglsøgaard in eastern Jutland in 2002 came a rare opportunity to investigate a bog with abundant traces of peat cutting and subsequent ritual deposition dating to the Early Iron Age. Pollen analyses show that before, during and after the ritual deposition, the bog lay in an open cultural landscape surrounded by arable fields and pastures. Around 180 cal B.C., extensive peat extraction commenced in the bog, targeting the well-humified wood peat that had formed during the Atlantic period and could be found in the deeper layers. In this relatively tree-less area, the primary aim of the peat cutting was presumably the acquisition of fuel. It is estimated that $250-500 \mathrm{~m}^{2}$ of peat was removed, leaving the bog with numerous small water-filled pits, i.e. peat cuts.

These water-filled peat cuts had a secondary role as elements in ritual activities in which depositions were made of pottery vessels, parts of domestic animals, wooden objects, bundles of flax, quantities of white/light-coloured stones etc. More than 130 pottery vessels from period II of the Pre-Roman Iron Age (250-1 cal B.C.) have been excavated at the site. ${ }^{14} \mathrm{C}$ dates for Linum usitatissimum (common flax) stems in two pottery vessels assign the depositions to the period 180-1 cal B.C. All the depositions included white/light-coloured stones, and these appear to have been a general feature of many ritual depositions in wetlands at this time. As the peat cuts in the bog became overgrown, due to renewed peat accumulation, the depositions decreased and there appears to have been a clear link between the offerings and the presence of open water into which these could be lowered. During the entire period of use (i.e. peat cutting and deposition), the bog appears to have been open and without tree cover, presumably due to persistent grazing and/or haymaking. But at the turn of the millennium, the bog had lost its ritual significance and its surface became colonised by willow scrub.
\end{abstract}

ARTICLE HISTORY

Received

21 Oktober 2019;

Accepted

17 November 2020.

\section{KEYWORDS}

Prehistoric peat cutting;

Wetland archaeology;

Ritual depositions;

Pre-Roman Iron Age;

Pollen analysis.

\section{Introduction}

The bogs and wetlands of northwest Europe have provided us with a considerable and significant number of archaeological remains. Artefacts deposited in these wetland areas are often interpreted as ritual deposits representing offerings to the gods or spirits. The most frequent type of ritual deposit comprises everyday objects such as ceramic vessels, bones and wooden artefacts. In Denmark, most of these remains turned up during the extensive peat extraction that took place throughout the $19^{\text {th }}$ and $20^{\text {th }}$ centuries. The archaeological finds cover the entire prehistoric period, but the Early Iron Age especially is strongly represented (Kaul 2003, 3236). They include of course the well-preserved and internationally renowned bog bodies - Grauballe Man and Tollund Man - intact with both skin and hair due to the bog's preservative properties (Asingh and Lynnerup 2007; Fischer 1980, 2007). Similarly, the great war booty offerings in Nydam Mose, Illerup Ådal and Ejsbøl Mose (Rau 2010; Rieck 2013, 2014; Ilkjær 1994, 2008; Ørsnæs 1988; Jørgensen and Andersen 2012; Christensen et al. 2012), and magnificent objects such as the Gundestrup Cauldron and the Dejbjerg Wagon (Petersen 1888; Kaul 1991) were also discovered during peat cutting. The same is true of a huge number of 
less conspicuous, but just as important, objects of more mundane character, such as ceramic vessels, wooden tools and implements and animal bones (e.g. Becker 1948, 1971; Ferdinand and Ferdinand 1961; Andersen 1993a, 1993b; Lund 2002).

Most archaeological finds discovered in bogs turned up many years ago and were largely recovered by laymen, without any actual professional archaeological excavation and scientific documentation. With very few exceptions, peat cutting is no longer undertaken in Denmark, and wetland areas are protected by the Nature Protection Act. Consequently, both discoveries of objects in bogs and archaeological excavations in wetland areas are now rare events. Despite the large quantity of finds recovered from bogs over time, we know remarkably little about the bogs with ritual deposits, and fundamental questions remain that have only been illuminated to a very modest degree: Was it, for example, specific wetland areas that were used for offerings? Were these wetlands located in the open, cultivated landscape or in more marginal areas, for example forests and woodland? Were the offerings placed on the surface of the bog or lowered into the water?

It is not possible to answer these and several other pertinent questions based on the archaeological objects alone, but only through complementary investigations of the sites in order to reconstruct their environmental history. These sites unfortunately no longer exist, as peat cutting and subsequent drainage has removed most wetland deposits.

With the discovery in 2002 of a bog sealed below a colluvium at Fuglsøgaard near Mariager Fjord, a rare opportunity arose to investigate one of the wetland sites with extensive ritual deposits from the Early Iron Age using modern archaeological and palaeoecological methods and thereby to come a little closer to answering some of the questions above.

\section{Site description}

Fuglsøgaard Mose lies south of Mariager Fjord in eastern Jutland (56 40’06.66”N 10¹2'37.48”E) (Figure 1). The site lies in a small hollow measuring c. $100 \times 200 \mathrm{~m}$ and appears today as cultivated agricultural land and it is, therefore, not covered by the Nature Protection Act. During the course of drainage work in the winter of 2002, several ceramic vessels were encountered and a subsequent investigation of the drainage ditch, together with excavation in plan, revealed a peat bog containing numerous pits, sealed beneath the plough soil (Figure 2) (Fiedel 2003, 69; Christensen and Fiedel 2003, 87-91). The bog's original peat layers appeared dark on the exposed surface, while the pits contained much lighter-coloured peaty deposits. During the excavation it became clear that these pits were prehistoric peat cuts and that it was ex-

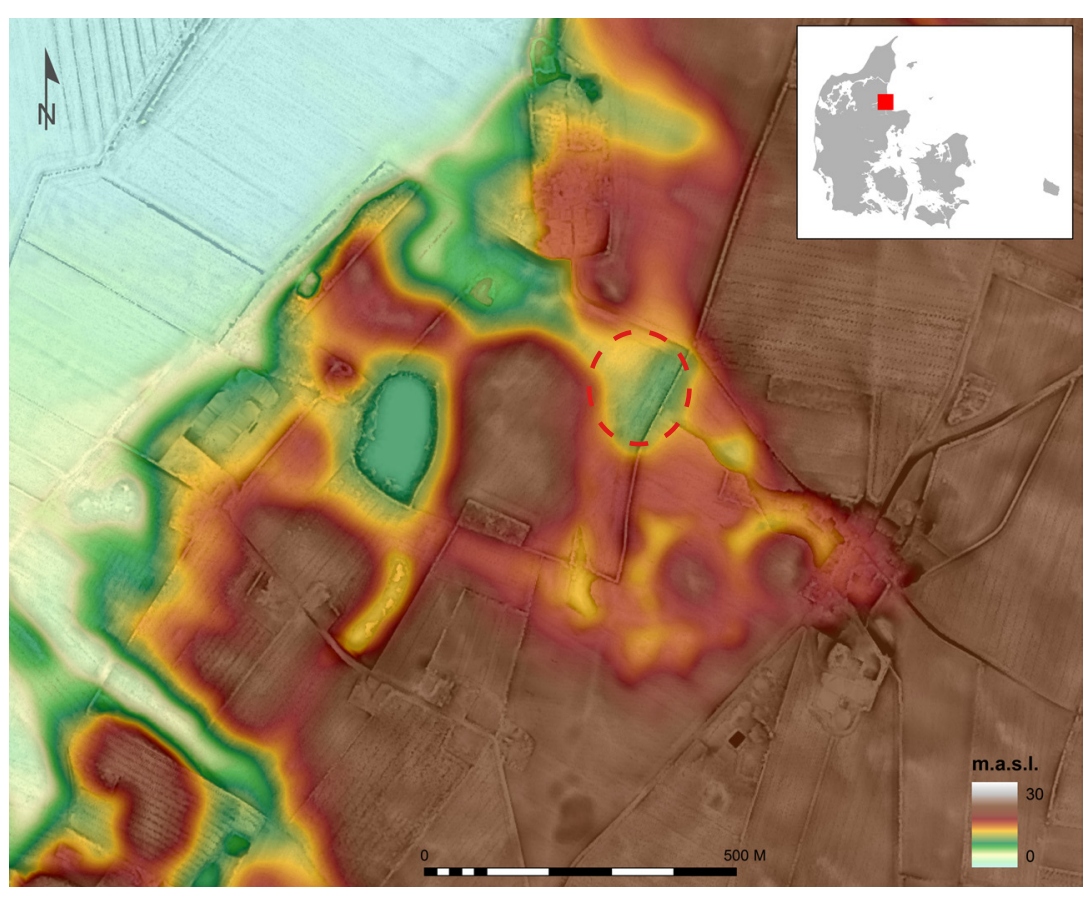

Figure 1. Fuglsøgaard Mose is located in eastern Jutland. The studied area is marked with a red broken line (Map: A. Pihl). 


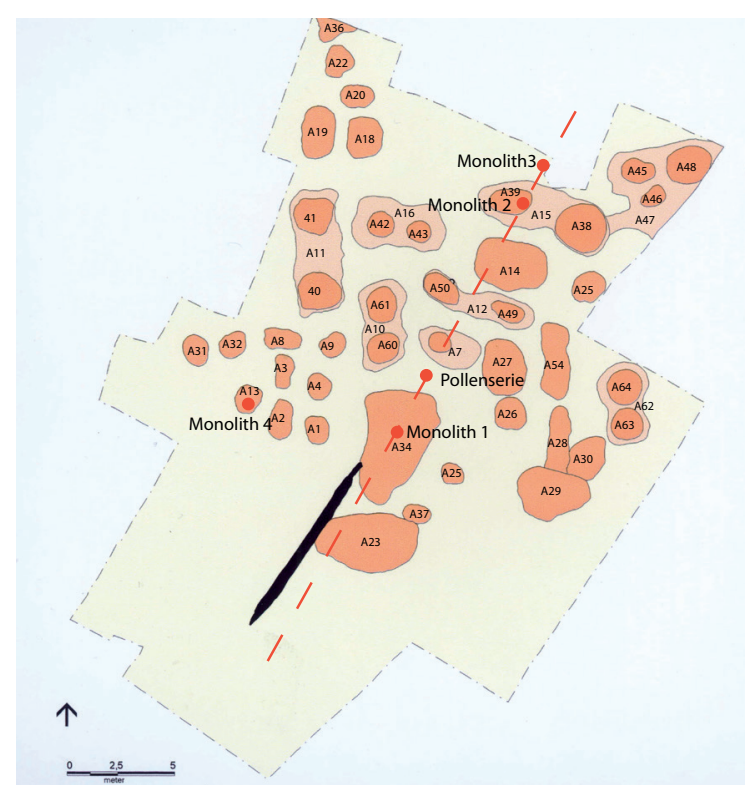

A

Figure 2. Overview of the bog showing the peat cuts in the central part. Red dots: Sediment sample columns (A). To the left $(B)$ and in the bottom $(C)$ is shown the peat cuts in plan and section, respectively. (Plan: R. Stidsing; Photos: R. Fiedel).

clusively in these features that the pots and other deposited objects lay. The extent of the bog was established by digging trial trenches and a total area of $1765 \mathrm{~m}^{2}$ was uncovered, corresponding to about $25 \%$ of the presumed area of the site, containing 81 pits, which varied between $0.5-3 \mathrm{~m}$ in surface diameter and had a depth of 0.5-1.7 m. A total of 52 peat cuts were excavated and more than 130 ceramic vessels were recovered, all of a type belonging to period II of the Pre-Roman Iron Age, i.e. corresponding to 250-1 cal B.C. (Jensen 2005; Johannesen 2016, 33). Several of the vessels contained birch twigs, bundles of flax steams, bones and stones, and one vessel was found to contain the remains of a puffball mushroom (cf. Calvatia $s p$.). The finds also included wooden objects such as clubs, tethering pegs, possible wagon components and other items of worked wood (Mikkelsen 2004). The relatively few bones that were found could be identified as cattle, horse and sheep/goat (Gotfredsen 2004). In the slightly acidic peat layers, the preservation conditions for bone would generally have been poor and it must be assumed that the faunal material is underrepresented. Apart from the bones, the state of preservation of organic material in the peat cuts is good as the bog, prior to 2002, had not been drained to the depth of the archaeological layers. Furthermore, the peat de-
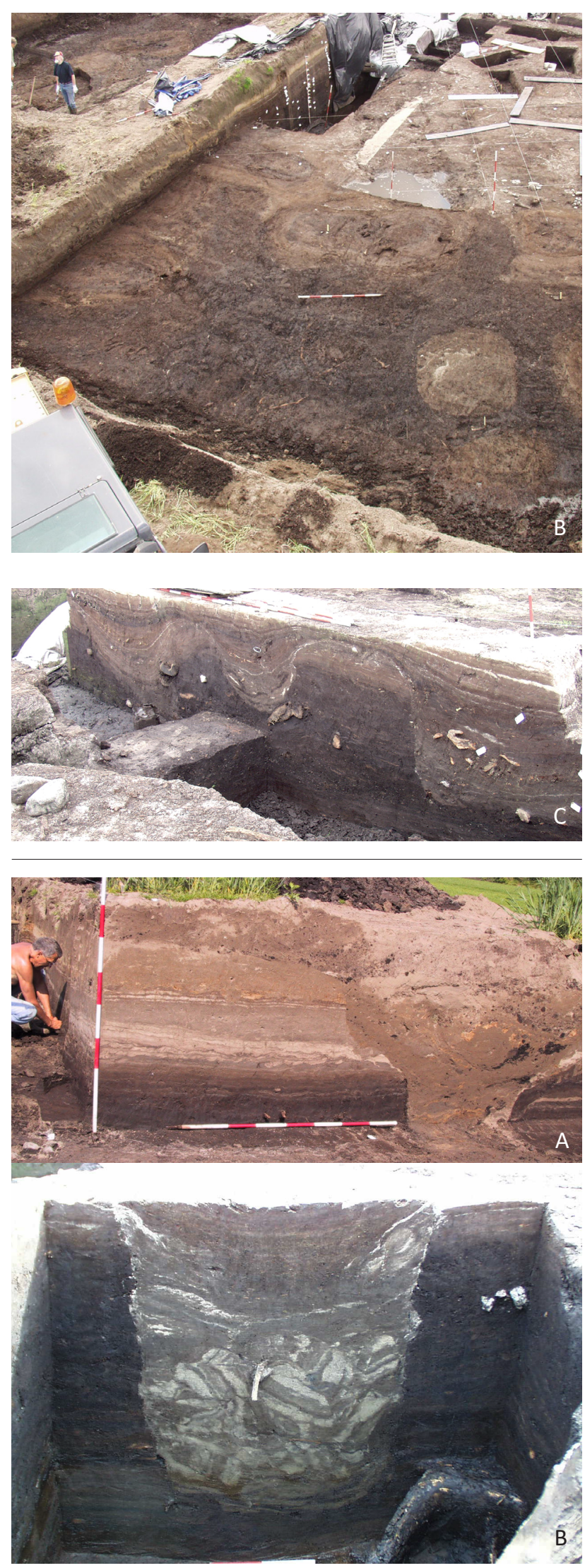

Figure 3. Sand and soil deposits overlaying the peat deposits. The feature on the right-hand side is a modern drainage ditch (A). B shows a peat cut refilled with sandy turves. This situation indicates that parts of the bog were already covered by sandy deposits in the Iron Age; probably colluvium washed out over the bog as a consequence of prehistoric field cultivation (Photos: R. Fiedel). 
posits had been sealed by a thick layer of clay-rich sand colluvium, which had been washed/ploughed down from higher terrain surrounding the bog (Figure 3).

During the excavation, samples were taken for further archaeological and scientific investigations. In addition to these, several vessels were sampled for analysis of pollen and plant macro-remains. For a detailed account of the archaeological excavation and processing of the archaeological finds, see Johannesen (2016). Several excavation photographs of the peat cuts and artefacts are presented in the supplementary data. This article focuses on the geological development of the bog, the prehistoric peat cutting and the ritual depositions. The primary aims were to investigate when the peat cuts were established, the nature of the surroundings of the bog before, during and after the active period (i.e. peat cutting and ritual deposition) and for how long it was possible to make offerings in the pits before they grew over due to renewed peat accumulation. Iron Age peat cutting and the presence of stones in bogs are also discussed.

\section{Materials and methods}

\section{Stratigraphy}

During the archaeological excavation, the bog deposits were exposed in open sections in several places (Figure 2), which permitted a detailed examination and description of the stratigraphy. The sections were surveyed and drawn, and the sediments described during the excavation. At the sampling points for the sediment columns for scientific analysis, the stratigraphy was described according to the Troels-Smith system (Troels-Smith 1955). Sediment sample columns were taken in three peat cuts which represent the growing-over phase (recurrence of peat accumulation) after the peat-cutting operations, while two sample columns were taken at places where there was natural accumulation of sediments reflecting the bog's development (Figure 2). Four of these five sample columns were subsequently subjected to pollen analysis. In this article, the results are presented from the analysis of sample column 3, which represents the undisturbed natural development of the bog, and sample column 1, which represents the regrowth and filling in of peat cut A34, which was one of the largest peat cuts. Sample column 4 was taken in a smaller peat cut (A13) and the pollen data is included as supplementary data. The deposits proved to be disturbed and the pollen diagram is not shown.

\section{Chronology}

Series of $2 \mathrm{~cm}$ thick sediment samples were taken from sample columns 1 and 3, from which terrestrial macrofossils were extracted for AMS ${ }^{14} \mathrm{C}$ dating.

Samples of charcoal and non-charred plant macro-remains were pretreated for dating using the standard acid-base-acid protocol. The samples were then converted to $\mathrm{CO}_{2}$ by combustion in sealed, evacuated quartz tubes with $200 \mathrm{mg}$ precleaned $\mathrm{CuO}$. The $\mathrm{CO}_{2}$ was reduced to graphite by the $\mathrm{H}_{2}$ reduction method using an iron catalyst and $\mathrm{MgClO}_{4}$ to remove the water. Samples were radiocarbon dated with the HVEE $1 \mathrm{MV}$ Tandetron accelerator at the Aarhus AMS Centre (AARAMS), Aarhus University, Denmark (Olsen et al. 2016). The ${ }^{14} \mathrm{C}$ ages have been fractionation corrected using online AMS $\delta^{13} \mathrm{C}$ and converted to calendar years using $\mathrm{OxCal} 4.3$ with the international calibration curve, IntCal13 (Bronk Ramsey 2009; Reimer et al. 2013).

In the case of column 1, a P_sequence function was used to construct an age-depth model for the renewed peat accumulation (growing over) in the peat cut (Bronk Ramsey 2008). Several samples were taken from column 3 to date the natural accumulation of sediments, but the organic layers were heavily humified and only a few samples contained sufficient identifiable material for a ${ }^{14} \mathrm{C}$ analysis. Two ceramic vessels $(\mathrm{x}-129$ and $\mathrm{x}-534)$ from peat cuts A23 and A40, respectively, contained stems and seeds of Linum usitatissimum (common flax), from which a sample was taken to AMS date their deposition (Figure 4). 

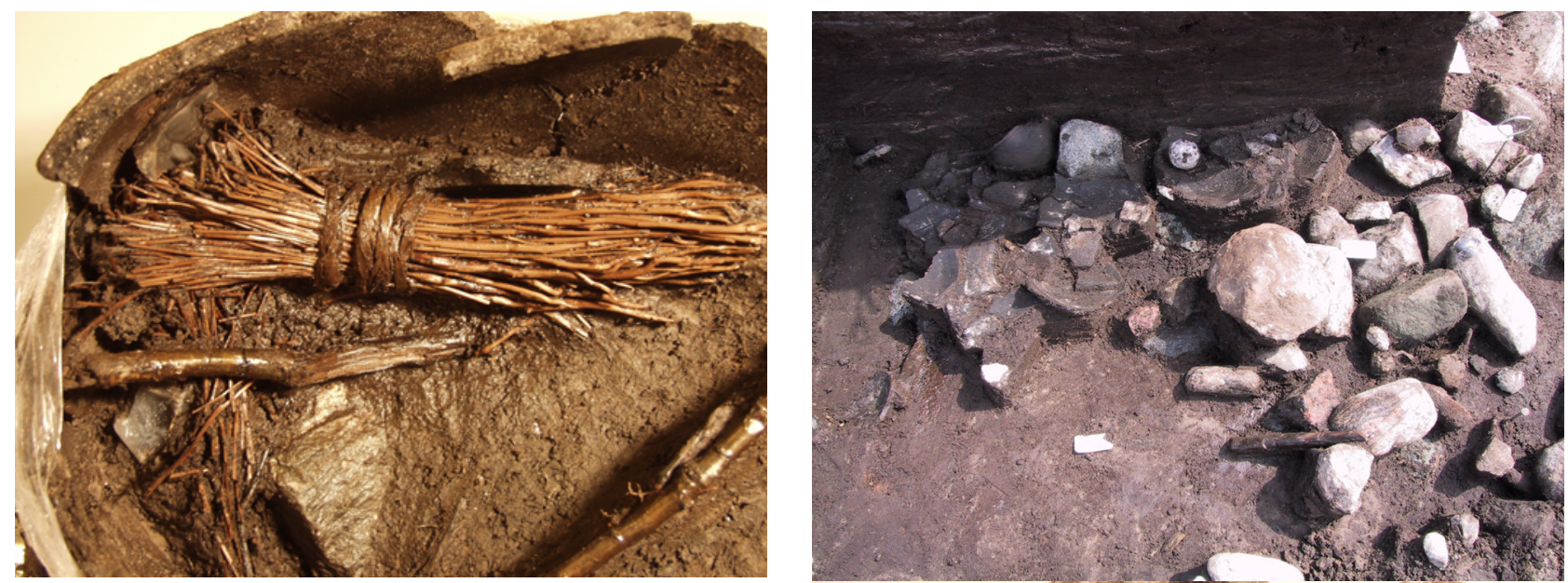

Figure 4. Ceramic vessel (x-534) containing a bundle of flax, found in a peat cut (A40). The flax bundle from this vessel, dated typologically to period II of the Pre-Roman Iron Age, has been ${ }^{14} \mathrm{C}$ dated to $180 \mathrm{cal} \mathrm{B.C.} \mathrm{-} \mathrm{cal} \mathrm{A.D.} \mathrm{136.} \mathrm{With} \mathrm{refe-}$ rence to this, the date for the deposition can be narrowed down to between 180-1 cal B.C. A23 is one of the largest and most finds-rich peat cuts in the bog. The exposed top layer, with stones, pottery vessels and wooden objects, can be seen here (Photos: R. Fiedel).

\section{Pollen analysis}

A total of 35 pollen samples were analysed, of which most are presented here. The samples were prepared for analysis using standard methods, which include treatment with $\mathrm{KOH}, \mathrm{HCI}$ and HF, as well as acetolysis (Fægri and Iversen 1989, 77-81). The residue from this process was then transferred to, and mounted in silicone oil, and an average of 500 pollen grains of terrestrial plants was counted per sample, as well as algae, spores and other microfossils. Entire microscope slides were analysed to account for any uneven distribution of pollen grains under the coverslip. Pollen was identified by reference to Fægri and Iversen (1989) and Moore et al. (1991), supplemented by the Danish National Museum's pollen reference collection. As the sediments were partly formed as a direct consequence of human activity, and these sedimentary changes are clearly evident in the stratigraphy, these boundaries have been used in the zonation of the pollen diagrams. As the bog covered an area of 2 ha at most, and the individual peat cuts are only a few square metres in extent, the relevant pollen catchment is limited to a maximum of a few hundred metres (Sugita 1994) and the pollen data therefore mainly reflect the very local environment in and around the bog.

\section{Results and interpretation}

\section{Chronology}

The results of the AMS ${ }^{14} \mathrm{C}$ dates are shown in table 1 and figure 5 .

Sample column 3, the natural development of the bog It was difficult to examine the chronology of the bog's natural development due to the generally poor preservation conditions in these sediments. Consequently, it was only possible to find datable terrestrial material at two levels. The lower AMS ${ }^{14} \mathrm{C}$ date (AAR-26054) from level $8.61 \mathrm{~m}$ a.s.l. is in the later part of the Neolithic $(2737 \pm 137 \mathrm{cal}$ B.C.) which concurs with the results of the pollen analysis. The upper date (AAR-26055) is from level $8.71 \mathrm{~m}$ a.s.l., and should therefore be younger, but actually falls at the end of the Mesolithic (4201 $\pm 131 \mathrm{cal}$ B.C.) and must be considered an outlier. The dated material had possibly been redeposited. It has therefore not been possible to construct an age-depth model for the bog's natural development. The poor preservation was undoubtedly due to the early peat deposits being formed in a woodland bog, where plant macro-remains often survive badly, whereas the growth of peat in the water-filled peat cuts took place under optimal conditions for the preservation of organic material. 


\begin{tabular}{|c|c|c|c|c|c|c|c|}
\hline $\begin{array}{l}\text { Lab ID } \\
\text { AAR- }\end{array}$ & Material & $\begin{array}{l}{ }^{14} \mathrm{C} \text { age } \\
{ }^{14} \mathrm{C} \text { years } \\
\text { BP }\end{array}$ & $\begin{array}{l}\text { Calibrated age } \\
95.4 \% \text { confidence } \\
\text { interval(s) }\end{array}$ & $\begin{array}{c}\text { Model } \\
\text { agreement }\end{array}$ & $\begin{array}{c}\text { Outlier } \\
\text { (posterior/prior) }\end{array}$ & $\begin{array}{l}\text { Calibrated age (modelled) } \\
95.4 \% \text { confidence interval(s) }\end{array}$ & Location \\
\hline BASE & & & & & & $\begin{array}{l}341 \mathrm{BC}-333 \mathrm{BC}(0.5 \%) \\
318 \mathrm{BC}-308 \mathrm{BC}(0.6 \%) \\
280 \mathrm{BC}-95 \mathrm{BC}(92.6 \%) \\
88 \mathrm{BC}-67 \mathrm{BC}(1.6 \%)\end{array}$ & Cut $A 34,8.35 \mathrm{~m}$ a.s.I. \\
\hline 21327 & $\begin{array}{l}\text { Corylus } \\
\text { (Charcoal) }\end{array}$ & $2168 \pm 25$ & $\begin{array}{l}357 \mathrm{BC}-275 \mathrm{BC}(50.0 \%) \\
258 \mathrm{BC}-160 \mathrm{BC}(44.0 \%) \\
129 \mathrm{BC}-117 \mathrm{BC}(1.4 \%)\end{array}$ & $62.5 \%$ & & $\begin{array}{l}329 \mathrm{BC}-307 \mathrm{BC}(1.1 \%) \\
235 \mathrm{BC}-86 \mathrm{BC}(92.4 \%) \\
76 \mathrm{BC}-56 \mathrm{BC}(1.9 \%)\end{array}$ & Cut $A 34,8.38 \mathrm{~m}$ a.s.I. \\
\hline 21324 & Unident. & $2039 \pm 27$ & $\begin{array}{l}158 \mathrm{BC}-132 \mathrm{BC}(5.0 \%) \\
115 \mathrm{BC}-\mathrm{AD} 26(90.4 \%)\end{array}$ & $116.4 \%$ & & $90 \mathrm{BC}-\mathrm{AD} 17$ (95.4\%) & Cut $A 34,8.63 \mathrm{~m}$ a.s.I. \\
\hline 21325 & $\begin{array}{l}\text { Calluna } \\
\text { vulgaris }\end{array}$ & $1880 \pm 26$ & AD 71 - AD 216 (95.4\%) & $104.0 \%$ & & AD 53 - AD 135 (95.4\%) & Cut A34, $8.88 \mathrm{~m}$ a.s.I. \\
\hline 21326 & $\begin{array}{l}\text { Vaccinium } \\
\text { uliginosum }\end{array}$ & $1868 \pm 25$ & AD 78 - AD 223 (95.4\%) & $79.4 \%$ & & AD 125 - AD 238 (95.4\%) & Cut A34, 9,15 m a.s.I. \\
\hline TOP & & & & & & AD 135 - AD 360 (95.4\%) & Cut $A 34,9.20 \mathrm{~m}$ a.s.l. \\
\hline 21323 & $\begin{array}{l}\text { Ranunculus } \\
\text { flammula }\end{array}$ & $2007 \pm 25$ & $53 \mathrm{BC}-\mathrm{AD} 61$ (95.4\%) & $99.7 \%$ & Outlier & 53 BC - AD 61 (95.4\%) & Cut $A 34,8.35 \mathrm{~m}$ a.s.I. \\
\hline 8886 & Linum & $2080 \pm 55$ & $\begin{array}{l}349 \text { BC }-308 \text { BC (4.1\%) } \\
208 \text { BC - AD } 53(91.3 \%)\end{array}$ & & & & Pottery vessel $x-129$ pit $A 23$ \\
\hline 8885 & Linum & $1990 \pm 65$ & $180 \mathrm{BC}-\mathrm{AD} 136(95.4 \%)$ & & & & Pottery vessel $x-534$ pit $A 40$ \\
\hline 26054 & Unident. & $4138 \pm 24$ & $\begin{array}{l}2874 B C-2619 B C \\
(94.7 \%) \\
2605 B C-2601 B C \\
(0.7 \%)\end{array}$ & & & & Baulk, $8.61 \mathrm{~m}$ a.s.l. \\
\hline 26055 & Unident. & $5377 \pm 32$ & $\begin{array}{l}4332 B C-4223 B C \\
(66.9 \%) \\
4207 B C-4159 B C \\
(16.8 \%) \\
4131 B C-4070 B C \\
(11.7 \%)\end{array}$ & & & & Baulk, $8.71 \mathrm{~m}$ a.s.l. \\
\hline
\end{tabular}

Table 1. Results of ${ }^{14} \mathrm{C}$ dates obtained for terrestrial plant material from sample column 1 (A23), the vessels and from the baulk.

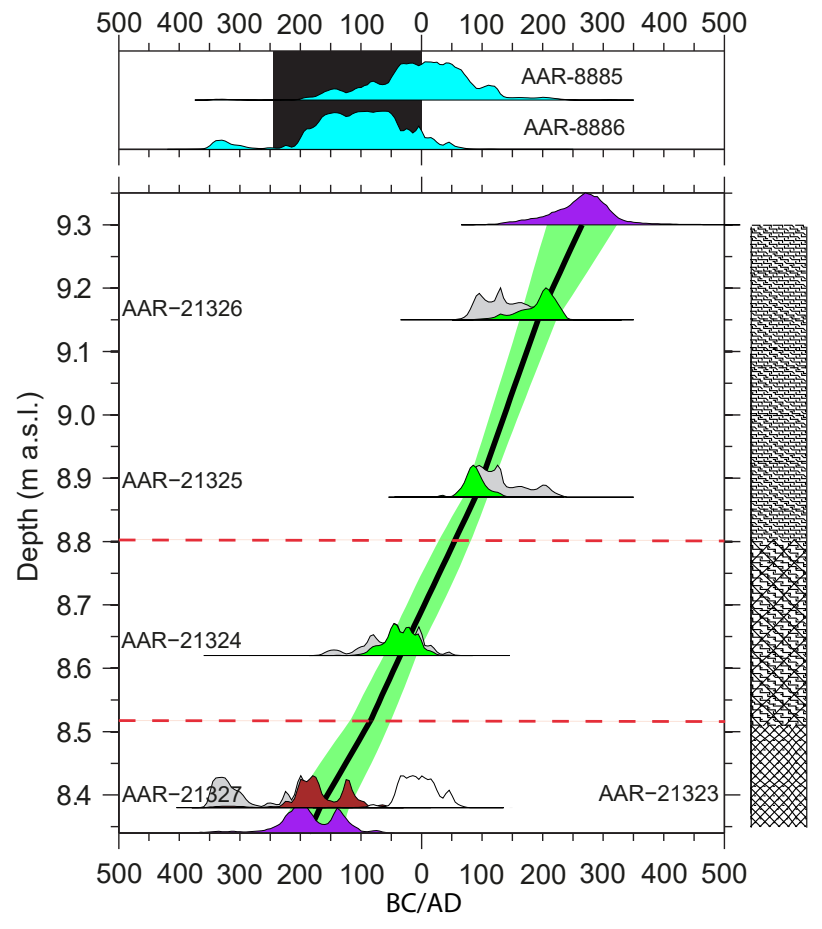

Figure 5. Below: Age-depth model for sample column 1. The boundaries are interpolated top and bottom ages for the sequence. The transition boundary indicates the shift from gyttja to peat/gyttja (offering/no offering phase). Above: $14 \mathrm{C}$ dates for ceramic vessels. The black area indicates the expected age range for the vessels as inferred from Johannesen (2016). Legend of sediment column see figure 7 (Model: J. Olsen).

\section{Sample column 1, peat cut A34}

The age-depth model for peat cut A34 (Figure 5) was constructed with the aid of a $\mathrm{P} \_$sequence function in $\mathrm{OxCal}$ 4.3. Of the five dates obtained, four were used to construct the age-depth model, while date AAR-21323 appears to be too young and must be considered an outlier. The age-depth model shows that the basal deposits were formed in $182 \pm 54$ cal B.C., which must be the time immediately after peat was extracted from the peat cut. The transition between zones A34-1 and A34-2 here is dated to $83 \pm 33 \mathrm{cal}$ B.C., and between zones A34-2 and A34-3 to cal A.D. 54 \pm 27 .

\section{Ceramic vessels}

Vessel x-129 from peat cut A23 is dated (AAR8886) to $2080 \pm 55$ (350 cal B.C. - cal A.D. 52), while vessel $\mathrm{x}-534$ from peat cut $\mathrm{A} 40$ is dated (AAR-8885) to $1990 \pm 65$ (180 cal B.C. $-\mathrm{cal}$ A.D.136). In chronological terms, the vessels belong typologically to period II of the Pre-Roman Iron Age, which extends from 250-1 cal B.C. (Jensen 2005). 


\section{Stratigraphy and pollen analysis}

\section{Sample column 3}

Sample column 3 was taken in the middle of the small basin and represents the natural development of the bog (Figure 6). The sample series has a depth of $1 \mathrm{~m}$ and covers the upper part of the bog's stratigraphy. Deeper gyttja deposits have been demonstrated in cores from the bog, and pollen analysis of these assigns them to the early Holocene period (not shown).

\section{FU-1}

This layer consists of heavily humified wood peat containing branches and trunks. The bog was dominated at this time by relatively dense woodland of Alnus (alder) and Betula (birch), while the surrounding woodland was dominated by Corylus (hazel) and Quercus (oak), mixed with Ulmus (elm) and Tilia (lime). At one level (8.5 $\mathrm{m}$ a.s.l.), the value for Alnus pollen is $85 \%$. This is presumably due to the sample containing an anther of Alnus, which is heavily overrepresented as a result. In mitigation of this problem, the proportion of Alnus pollen at this level has been reduced to the mean value of the two adjacent samples. Very few pollen grains of open-landscape plants are present, and there are no indications of arable land within the pollen catchment area. It must therefore be assumed that this wood peat was formed in the Atlantic period prior to the introduction of agriculture.

\section{FU-2}

The transition between zones FU-1 and FU-2 corresponds to a change in the bog's hydrology. The Atlantic woodland peat is overlain by fen peat containing some gyttja, and the wetter conditions in the bog are similarly reflected by a marked increase in Sphagnum (bog moss) spores. Based on the presence of cultural indicators such as Plantago lanceolata (ribwort plantain) and Hordeum (barley), these sediments must have been formed after the introduction of agriculture around $4000 \mathrm{cal}$ B.C. (Odgaard 2006, 333). This is consistent with the ${ }^{14} \mathrm{C}$ date (AAR-26054) for level $8.61 \mathrm{~m}$ a.s.l., which cal dates the lower part of FU-2 to 28742601 B.C. It is possible that the wetter environment was a consequence of a local rise in the water table associated with woodland clearance in the vicinity, coupled with the climatic changes that took place at the beginning of the Neolithic period in Denmark (Berglund 2003).

The pollen diagram shows that Betula was the dominant taxon but, unlike in zone FU-1, there are no preserved branches or trunks. This means there were no trees growing on the actual bog at this time, but there was Betula woodland around the margin of the bog, mixed with Alnus. In the upper part of the zone, values of Poaceae (grass family) begin to rise, and there is also a general increase in herbs such as Spergula arvensis (common spurrey) and Chenopodiaceae (goosefoot family). Together with Plantago lanceolata and Hordeum, this shows there must have been arable fields and

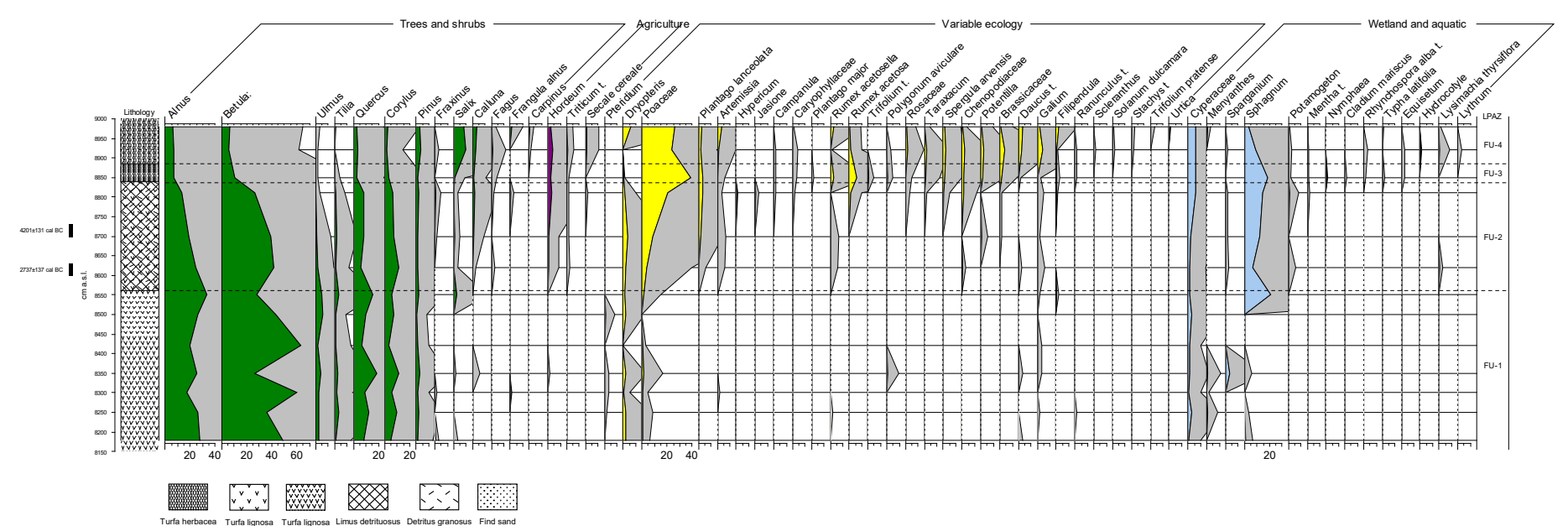

Figure 6. Percentage pollen diagram for sample column 3 showing selected taxa. The diagram shows the bog's natural development. The pollen percentages have been calculated on the basis of the terrestrial taxa. The shaded area shows a x10 exaggeration of the percentage values (Diagram: M. F. Mortensen). See also: Fig.6 large scale. 
pastures on the dry land around the bog. There is nothing in the development of the vegetation to suggest that the stratigraphy is disturbed, but given the old date obtained at level $8.71 \mathrm{~m}$ a.s.l., this possibility cannot be discounted.

\section{FU-3}

In zone FU-3, the blackish-brown and generally highly humified peat is replaced by light-brown moderately-to-poorly fibrous peat. This sedimentary change indicates that the hydrological conditions in the bog developed further towards an even wetter environment. In the vegetation, a dramatic reduction is seen between FU-2 and FU-3 in the proportion of forest trees, while grasses and open-landscape plants, such as Rumex acetosa (common sorrel) and Rumex acetosella (sheep's sorrel) increase markedly. This development indicates that the area around the bog had become open arable land. Grazing land was dominant, and the bog itself may possibly have been grazed too, before the first peat cuts were established. The wetter conditions were probably a consequence of the shift to a wetter climate that occurred at the end of the Late Bronze Age, the so-called 2.8k event. This has been recorded at a number of localities in Denmark and across Northwestern Europe as a whole (van Geel and Renssen 1998, 24-27). In Denmark, the $2.8 \mathrm{k}$ event resulted in a higher water level in many lakes and bogs and many low-lying areas became waterlogged (Christensen and Mortensen 2011). It is evident in several of the peat cuts that FU-3 has been cut through by the peat cutting which, consequently, took place after this deposit was formed (Figure 2). The light-brown, fibrous fen peat of FU-3 must therefore have formed the surface of the bog when the peat cutting began, and the upper part of this layer may therefore have been disturbed.

\section{FU-4}

At the transition to this zone, peat-cutting operations came to a halt. The peat in FU-4 can be seen to consist of several separate layers, but these are addressed here as one. As can be seen from figure 2, the peat accumulated in the peat cuts and over the baulks between them. Subsequently, the activities in the bog appear to have ceased and the bog surface became colonised by willow scrub. This zone has high values of Salix (willow) pollen, which can be traced over the investigated part of the bog. The surrounding landscape was open, with minimal tree cover, and subject to heavy cultural influence.

\section{Sample column 1, peat cut A34 (Figure 7a, b)}

A34 is one of the largest peat cuts in the bog and few ceramic vessels, crushing stones, flint flakes and wooden artefacts of unknown function were deposited in it. A34 lies beside A23, which is the most finds-rich of all the peat cuts here. Parts of at least 36 vessels, 24 of which were more or less complete, were deposited in A23 in addition to a number of other artefacts such as club heads, tethering stakes, worked planks, and bones of at least three sheep/goats and four cattle, most of which were from the heads and legs. A23 and A34 are located close to the edge of the bog near a large oak trunk, which presumably functioned as a walkway alongside the peat cuts and during the subsequent depositions (Johannesen 2016, 38-39).

\section{A34-1 (182 \pm 51 cal B.C. to $83 \pm 54$ cal B.C.)}

This zone represents the time just after establishment of the peat cut. During this ca. 100-year period, the peat cut was filled with water, and sandy gyttja became deposited at its base. This sandy content was probably washed in from the surrounding baulks and the dry land around the bog. In other peat cuts thrown-in fill was found, consisting of large blocks (turves) of sandy material. This backfill must originate from deposits in the marginal zone that no longer exist, because they were dug away and removed during the Iron Age peat extraction (Figure 3). The low values for algae and pollen of aquatic plants recorded here are probably due to the water being brown and discoloured as a result of its humus content from the surrounding peat, which reduced the penetration of light. Fen plants such as Lythrum salicaria (purple loosestrife) and Iris pseudacorus (yellow flag iris) gradually became established, together with members of the Cyperaceae (sedge family); presumably Carex rostrata (bottle sedge), which is often found in former peat cuts. Calluna vulgaris (common heather) and Poaceae (grass) are the dominant pollen taxa and bear witness to the open cultural landscape that existed in and around the bog. Indications of grazing and crop cultivation are evident in the form of Plantago lanceolata and 


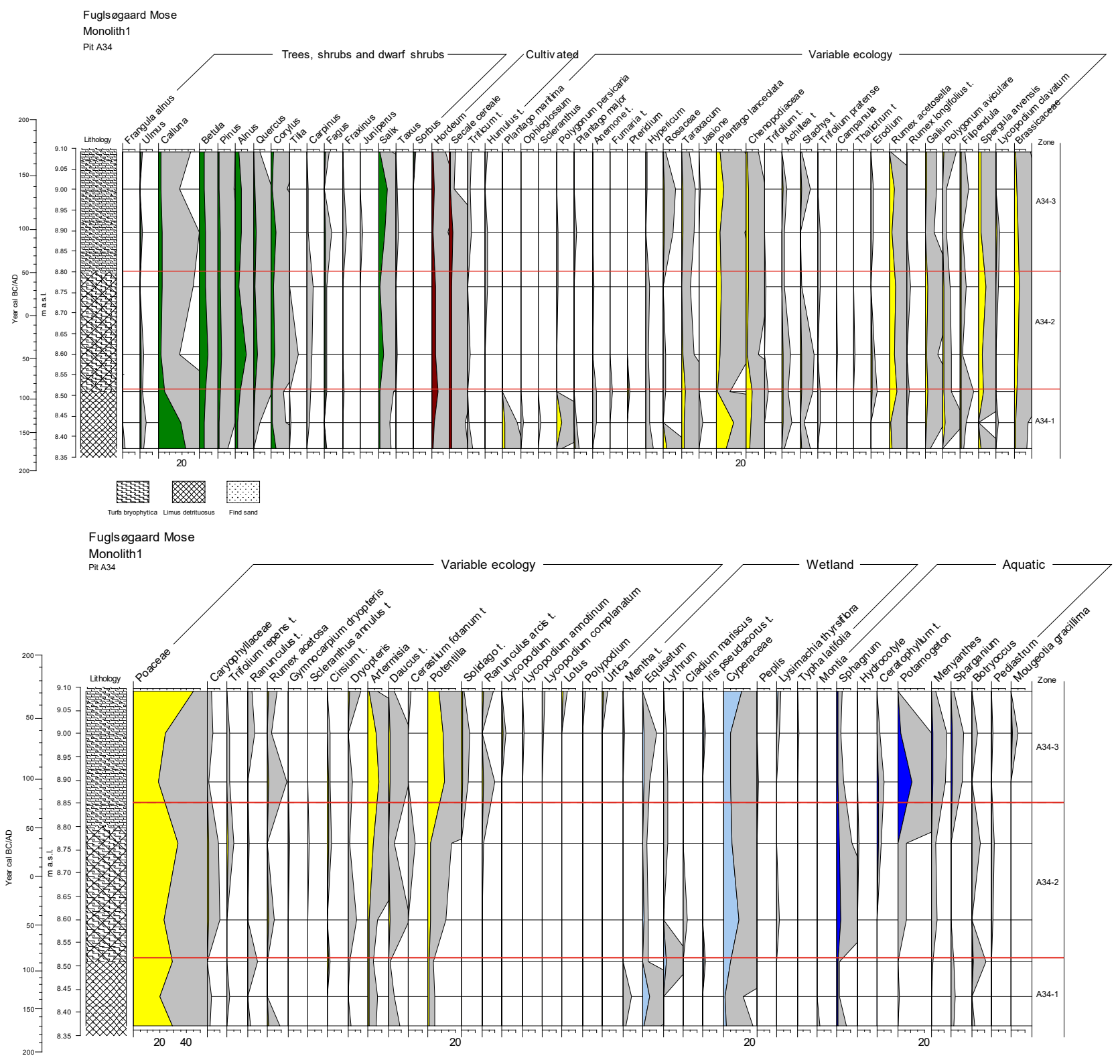

Figure 7. Percentage pollen diagram for sample column 1 showing selected taxa. The diagram shows the regrowth of peat in a peat cut. The pollen percentages were calculated on the basis of terrestrial taxa. The shaded area shows a $\times 10$ exaggeration of the percentage values (Diagram: M. F. Mortensen). See also: Fig.7 a,b large scale.

Rumex acetosella, together with cereal pollen: Hordeum, Triticum (wheat) and Secale cereale (rye).

\section{A34-2 $(83 \pm 22 \mathrm{cal}$ B.C. to cal A.D. $54 \pm 27)$}

The sediment here consists of peaty gyttja, and during this zone the peat cut changed from water-filled pit to level bog surface. The most important plants involved in the regrowth of peat were Cyperaceae (sedges) and Sphagnum, which resulted in the gradual infilling of the peat cut. Ultimately, continuous peat cover was restored, and extended over both the peat cut and the surrounding baulks. Calluna and Plantago lanceolata values decline, while those of Rumex acetosella, Spergula arvensis and Brassicaeae (mustard family) increase.

A34-3 (cal A.D. $54 \pm 27$ to cal A.D. $217 \pm 40$ )

The fen peat that covered the peat cuts and the baulks left between them corresponds to zone FU-4. As can be seen from figure 2, the deposits sink some way down into the peat cuts. In the sediment in these wet depressions, macro-remains have been found of Potamogeton polygonifolius (bog pondweed), which specifically grows on muddy and peaty substrates in former, shallow 
water-filled peat cuts (Schou et al. 2017, 80-81). Potamogeton polygonifolius was accompanied by Menyanthes trifoliata (bogbean) and Sparganium-t. (bulrush/burred). This vegetation was responsible for the formation of a dense, continuous peat deposit.

As in FU-4, there is an increased proportion of Salix pollen, indicating development of willow scrub on the bog following the cessation of peat cutting and ritual deposition in the peat cuts. This development is evident between $8.765 \mathrm{~m}$ a.s.l. (cal A.D. 39 \pm 28 ) and $8.895 \mathrm{~m}$ a.s.l. (cal A.D. 93 \pm 20 ), and the peak in Salix can be also be seen in FU-4 and peat cut A13 (supplementary data). The high values of Poaceae and open-landscape plants show that the area around the bog continued to be used generally for grazing animals and the cultivation of cereals.

\section{Sample column 4}

Sample column 4 was taken in a near-marginal peat cut (A13), from which no finds were recorded. The samples extend over a depth of $1.13 \mathrm{~m}$, through a peat cut containing regrown peat and the underlying peat deposits (supplementary data).

\section{A13-1}

This zone lies below the base of the peat cut and consists of the original "primeval" peat. The pollen spectrum is dominated by Pinus (pine), Corylus and Poaceae and only few pollen grains have been recorded of Tilia, Ulmus, Alnus and Quercus. Based on this, the peat must have been formed at the transition between the Boreal and Atlantic periods, i.e. around $7000 \mathrm{cal} \mathrm{B.C.}$

\section{A13-2}

The deposit in this zone consists of gyttja mixed with peat, which in its lower part is dominated by pollen of Quercus, Betula and Alnus. Values for these species decline gradually upwards, and a greater proportion of Poaceae, as well as several light-demanding herbs such as Artemisia (mugwort) and Spergula arvensis becomes evident. Cultivated species are also represented: Hordeum, Triticum and Secale cereale. The sediment here is interpreted as a mixed deposit: A result of older peat being intentionally thrown into the peat cut during the establishment of one of the neighbour- ing cuts, or sediment slipping into the peat cut from the surrounding peat wall. The proportion of "primeval" peat declines up through the deposit, and the pollen spectra begin to give a more correct picture of the vegetation and can, in this part, therefore be correlated with A34-2.

\section{A13-3}

This zone represents the continuous peat deposits that cover the entire bog. The pollen spectrum is dominated by Poaceae, Plantago lanceolata and Rumex acetosella pollen, together with Sphagnum spores, and the zone can be correlated with A34-3.

Of the more than 80 peat cuts identified in the bog, the pollen studies cover only two, together with the natural development of the bog as evident from a section. The question remains whether the results of the investigations are representative of the overall development in the bog and the regrowth of peat in the peat cuts. In general, it can be argued that all the peat cuts were dug into the same basic sediments and therefore have the same preconditions for regrowth of peat. Similarly, the upper peat deposits, which formed after the cessation of activities, can be traced across the entire bog and must, accordingly, have the same formation history. It is therefore assumed that the analyses are generally representative of the overall development despite some variation in the peat accumulation in the individual peat cuts, dependent on various factors such as the depth of the pit, its proximity to the edge of the bog and possibly backfilling with peat turves.

\section{Discussion}

\section{The landscape}

Ice age glaciers created a gently undulating landscape in Denmark with abundant basins and depressions in which shallow lakes formed as the ice melted. Through the Late Glacial and early Holocene, thousands of such lakes dominated the terrain across large parts of the younger moraine landscape.

The extent of these past lakes is suggested by maps from the beginning of the $19^{\text {th }}$ century, prior to widespread and intensive drainage, when as 
much as $25 \%$ of the land was occupied by wetlands. Many of these wetland areas have been investigated during archaeological and palaeoecological studies, and in the great majority of cases it is evident that these basins became filled with lake sediments and peat deposits during the first half of the Holocene and developed into bogs (e.g. Aaby 2008; Andersen et al. 1983; Mortensen et al. 2011, 2014).

Pollen studies show that the open cultural landscape we are familiar with today was formed on dry land as early as the Early Bronze Age (Odgaard and Nielsen 2009, 47). Consequently, the Early Iron Age therefore had an open and, in many places, largely treeless cultural landscape in which the numerous hollows and depressions featured bogs and meadowlands. Only the larger and/or deeper basins still appeared as lakes.

This description of the landscape is consistent with the present pollen diagrams from Fuglsøgaard Mose. Already before peat extraction began around

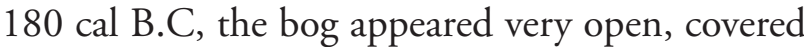
with Sphagnum and Cyperaceae, while around it there was an open and intensively exploited cultural landscape. In the proximity of the bog were arable fields, used to cultivate Hordeum, Triticum and perhaps also Secale cereale, while the hillier areas hosted commons and pastures, which were exploited for animal grazing and/or haymaking. In Denmark $S$. cereale becomes a regular cultivated crop from the Late Iron Age onwards. Finds of pollen and macrofossils show that $S$. cereale was present already from the Late Bronze Age, however, it is not clear if it was cultivated on a small scale or if it was present as an arable weed (Robinson 1994, 20-39; Henriksen et al. 2009, 251; Henriksen and Harild 2020, 543; Søgaard et al. 2018). The picture remained the same after peat cutting began and over the subsequent two centuries until the bog became overgrown and developed into willow scrub in the Early Roman Iron Age. If the bog had been abandoned immediately after the peat cutting, willow scrub would probably have colonised the baulks surrounding the peat cuts in the course of a few years, as seen in many places following cessation of peat cutting in the first half of the 20th century. The fact that it took two centuries before the surface of Fuglsøgaard Mose became covered in willow scrub could be due to the bog surface being kept open by regular haymaking or grazing of the remaining baulks.

It has previously been suggested that bogs with ritual deposits from the Iron Age were situated in inaccessible areas of woodland, meadow and bog (e.g. Ferdinand and Ferdinand 1961, 81), but this is an interpretation that can no longer be justified. Firstly, the bogs constituted a heavily exploited resource that, in addition to peat extraction, in many places took the form of wet meadows used for grazing and haymaking. Moreover, the willow vegetation growing on and around them could supply withies needed for basketry, wattle and so forth. It is clear from the pollen data that Fuglsøgaard Mose lay in an active cultural landscape in which people had their day-to-day activities before, during and in the centuries after the peat-cutting phase. A similar open cultural landscape is also evident at Rislev Valmose in western Sealand (Troels-Smith 1961, 92), Nydam Mose in southern Jutland (Kolstrup 2009, Christensen 2020, 315-317) and Aldersro I in mid Jutland (Skousen 2008, 346), that likewise contains ritual depositions. It is therefore obvious to conclude that these bogs during the Iron Age had a close association with the active arable land and habitation rather than being placed in a distant, marginal area. Perhaps this proximity to daily life was even a precondition for the selection of a bog as a ritual depositional site?

The close connection between habitation and bogs with ritual depositions is evident from the Roman Iron Age site near Skødstrup where a bog site with peat digging and ritual depositions were located close to the settlement (Mandrup et al. 2017). However, so far no settlements have been located in the vicinity of Fuglsøgaard Mose. A search in the Danish National database (Kulturarv. $\mathrm{dk}$ ) of archaeological finds shows that the closest traces of a pre-Roman Iron Age settlement is located approximately 1400 meters west of Fuglsøgaard Mose, while finds belonging to the early Roman Iron Age is recorded from the nearby village, Klattrup, 500 meters to the west of Fuglsøgaard Mose.

\section{Peat cutting}

Evidence of prehistoric peat cutting was first demonstrated in Denmark during the excavation 
of the Hjortspring Boat on Als (Rosenberg 1937, 28). It was possible here, both during the actual excavation and in the subsequent pollen studies, to establish that large quantities of peat had been extracted from the bog at the end of the Bronze Age. As a consequence, a lake was formed, in which the $19 \mathrm{~m}$ long Hjortspring Boat and associated weapons etc. were deposited several centuries later $(350 \mathrm{cal} \mathrm{B.C)}$. The excavators recorded several small pits below the gyttja deposits, which Rosenberg referred to as "ritual wells". The development of the Hjortspring basin can now be interpreted as follows: In the course of the Bronze Age, some small peat cuts were established from which peat was extracted. Later, presumably at a time of low water table, the remaining peat that stood between the earlier peat cuts was extracted by way of a more extensive horizontal peat-cutting operation (Christensen and Fiedel 2003, 95). Consequently, only the bases of the original pit cuts are preserved. The excavation at Hjortspring therefore provided us with tangible evidence of the two fundamental peat-cutting strategies that are known to have been practised in Danish prehistory: digging of small individual peat cuts and horizontal removal of peat from peat banks extending over larger areas.

These peat banks may extend over large areas and they may be difficult to recognise in the field as the transition between the old "primeval" peat and that formed when peat growth resumed after cutting can resemble a natural succession. It is, however, often first possible to detect this form of peat extraction by pollen analysis and/or ${ }^{14} \mathrm{C}$ dating. In addition to Hjortspring, horizontal peat extraction has been demonstrated in Nydam Mose (Christensen and Fiedel 2003, 95-96; Charlie Christensen 2020), Borremose (Christensen and Mortensen 2011), Aldersro II (Skousen 2008, 246-251) and Svennum Mose (Sidsel Wåhlin and Morten Fischer Mortensen unpubl. data). Horizontal cutting is the most efficient method of peat extraction but requires that the water can be effectively led away. At Aldersro II (Skousen 2008, 250-251) and Svennum Mose (Sidsel Wåhlin and Morten Fischer Mortensen unpubl. data) there are indications that ditches were dug in advance of the peat cutting to lower the water table in the bog. Elsewhere, it is assumed that horizontal peat cutting took place at the end of the Bronze Age before the wetter climate raised the water table in the Iron Age (Christensen and Fiedel 2003).

There is better evidence for the smaller, often circular, peat cuts that we know from Fuglsøgaard Mose. They have also been discovered at Nørre Smedeby (Becker 1948, 93) and the find site of Grauballe Man (Jørgensen 1956, 119), as well as at many other localities across Denmark (see Becker 1971). In the ritual depositions in the peat cuts, the artefacts are naturally concentrated in small, discrete heaps. It is therefore obvious to conclude that similar heaps of finds were deposited in separate, individual peat cuts. A review of previous finds suggests that finds such as the wagon wheels from Rappendam, the Gundestrup Cauldron from Rævemosen and several others must have been deposited in peat cuts (Christensen and Fiedel 2003, 92). Similar finds circumstances at localities such as Bukkerup, Turup, Rislev and Salpetermosen suggest, correspondingly, that the objects encountered here were also deposited in separate, individual peat cuts (Andersen 1993a, 72-72; Andersen 1993b, 203; Ferdinand and Ferdinand 1961, 50; Pantmann 2017).

In general, it must be assumed that all find assemblages recovered from bogs that contain preserved organic material in the form of bones, wood and other plant remains, were only preserved insofar as they came under oxygen-poor conditions quickly. If objects were placed on the surface of the bog, this would lead to swift degredation and humification of the organic parts before the peat managed to grow and cover them. All organic objects and materials found preserved in bogs must therefore either have been deposited in a naturally-formed lake, which subsequently grew over with peat, or lowered into a water-filled peat cut. Given the enormous quantities of archaeological finds that have been encountered in, and recovered from, Danish bogs over time, it must therefore be assumed that prehistoric peat cutting was much more widespread than has so far been realised.

Prehistoric peat-cutting implements, in the form of T-shaped and double spades, have been recorded from several localities (Lerche 1985, Lyngstrøm 2016). No tools have been found in Fuglsøgaard Mose that can definitely be linked to peat cutting, with the exception of small fragments of wood interpreted as the remains of peat spades 
Figure 8. No peat spades have been found in the bog, but these implements have clearly left their mark in the peat. It can be seen here how the peat cutters dug into the side of the peat cut (A). Double peat cut $A 38$ and A39 (B) (Photos: R. Fiedel).
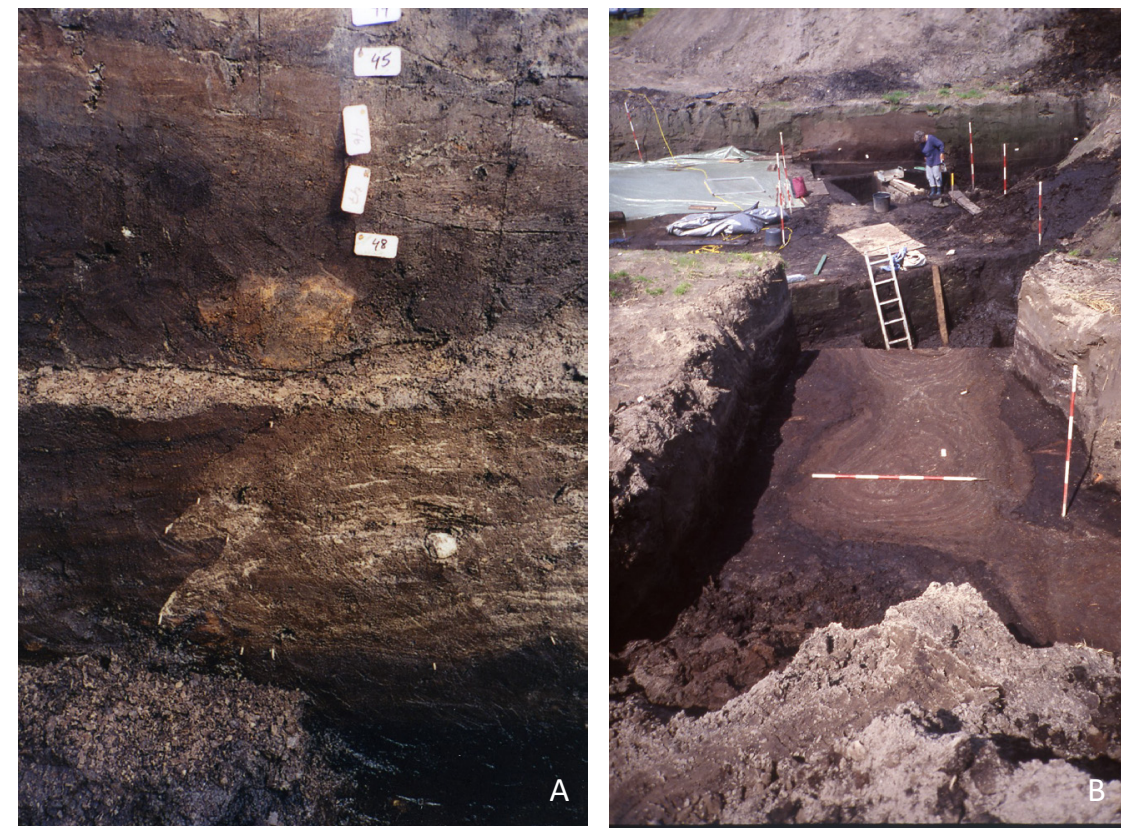

(Johannesen 2016, 163). On the other hand, traces left by the 10-12 cm broad peat spades are clearly evident in several of the peat cuts (Figure 8 and supplementary data). The Iron Age peat cutters were obviously interested in the well-humified Atlantic wood peat. In several places, they can be seen to have dug in under large tree trunks in order to make optimal use of the peat cut (Figure 8).

Iron Age peat cutting - like that of recent times - took place in spring and early summer, so that the peat could dry prior to storage for the winter (Hove 1983; Svendsen 2009, 21-23). Some deposits are so consolidated and firm that the peat can be cut directly out of the bog in appropriate blocks, so-called "cut peat", while others have a looser structure and the peat must be kneaded and formed prior to drying. There is an example from Nørre Smedeby of one of these "knead peats" with preserved finger impressions (Becker 1948, 98). After an initial drying phase, the peats were stacked up so the sun and not least the wind could dry them over the course of the summer. A peat stack has been found in Scotland that is dated to the Late Bronze Age. This peat stack was not taken home from the bog and subsequently became covered by peat growth and thereby preserved (Branigan et al. 2002).

Fuglsøgaard Mose lies in a depression with no natural runoff for the water. The less-efficient method of peat cutting, i.e. peat cuts rather than a linear peat bank, was therefore the only feasible option for extracting the peat. As it was not possi- ble to drain the bog, the peat cuts would relatively quickly fill up with water and their size may very well indicate how much peat could be extracted in the course of a working day. Because by the next day, water would have made peat cutting impossible. But the size of the peat cut may also have been governed by other factors. It is known from peat-cutting operations in the past how the base could "shoot up" if the peat cut became too large. This is a result of the surrounding peat pressing down on the underlying deposits; this excess pressure forces the basal deposits up through the peat cut (e.g. Jørgensen 1956, 122).

In some places, pairs of closely-spaced peat cuts - i.e. "double cuts" - are seen (Figure 8), where one has often been back-filled with thrown-in peat turves. It must be assumed that the pit containing the peat back-filling was dug first, after which a new peat cut was established immediately beside it. The first peat cut was then used for the disposal of peat of poor quality. As can be seen from figure 3, some of the discarded turves consist of almost pure sand, which means that, already in the Iron Age, parts of the bog must have been covered with colluvium, i.e. material eroded and washed down from the surrounding fields (cf. Figure 3).

An attempt can be made to estimate how much peat has been extracted from the bog. The peat cuts vary from around 0.5 to $3 \mathrm{~m}$ in diameter and 0.5 to $1.7 \mathrm{~m}$ in depth, and a cautious estimate shows that they had an average volume of 0.5 to $1 \mathrm{~m}^{3}$. Insofar as those peat cuts encountered are 
also representative of the situation in the $70 \%$ of the bog that has not been excavated, it can be calculated that between 250 and $500 \mathrm{~m}^{3}$ of peat was extracted.

There are no direct indications of what the peat was used for. It is known from the Middle Ages that peat mixed with the dung of domestic animals was employed for soil improvement on nutrient-poor soils (Aaby and Vegger 1995), and it is conceivable that this manuring technique was already employed in prehistoric times. But as peat turves of poor (fuel) quality were thrown back into the peat cuts, it seems unlikely that soil improvement was the primary aim of the peat cutting.

It seems reasonable to assume that the main purpose was the extraction of fuel for heating, cooking and iron production. Given the massive clearance of the woodland that took place in the second half of the Bronze Age (Odgaard and Nielsen 2009, 47), fuel was a limited resource, and in the most treeless areas peat was probably the primary fuel source. Not least because the local iron production from bog iron ore required abundant fuel resources for both the smelting and smithing processes (Lyngstrøm 2008). It is known from historical times that peat coal is well-suited to smithing (Christensen and Fiedel 2003, 97-98). Unlike charcoal, burnt peat only leaves traces in the form of ash and carbonised seeds from wetland plants in the most fortunate cases. Peat ash has, for example, been found in cremation graves (Olsen and Bech 1995, 12-14; Olsen et al. 1996, 170; Henriksen 2016, 46) and in a hearth (Henriksen 2001, 2; Henriksen et al. 2018; 407-408) in Thy, both dated to the Early Bronze Age.

Since the excavated part of the bog is penetrated by pits we must assume that all easily accessible peat was extracted and a new bog replaced Fuglsøgaards Mose as a peat source. The remaining baulks were not removed as seen in eg. Skødstrup (Mandrup et al. 2017), maybe because this removal is more time-consuming and therefore baulks were only used if there were no other peat areas in the vicinity.

\section{Ritual activities}

A central question associated with the ritual activities is: When did these take place and for how long was the bog used for ritual depositions? From the archaeological dating of the ceramic vessels we know that the primary depositions took place in the bog during period II of the Pre-Roman Iron Age, i.e. between 250 and $1 \mathrm{cal}$ B.C. In the case of both vessel x-534 in A40 and vessel x-129 in A23, this date can, via ${ }^{14} \mathrm{C}$ dating, be narrowed down to $180-1$ cal B.C. (Figure 5 and Table 1). It is not known whether all the peat cuts were established during the same short period or dug over a longer time. But as all the peat cuts are overlain by the same peat deposit, this suggests a brief period, presumably in the order of a few decades.

In most cases, the offerings were found incorporated into gyttja, but artefacts were only rarely encountered at the very base of the peat cut; they were usually found some way up in the gyttja. This demonstrates two important things:

That the peat cutting and the ritual depositions are not contemporaneous. The age-depth model for A34 indicates that several years or even decades could have elapsed between the peat cutting and the later ritual deposition. A similar situation is evident at Nørre Smedeby in southern Jutland, where several wooden bowls were deposited long after the peat cut had been established (Becker 1948, 93). Similarly, the ritual depositions at both Hjortspring and Nydam were undertaken long after the actual peat cutting, and the same applies to the bogs in which Tollund Man and Grauballe Man and other bog bodies were found (e.g. Fischer 2007, 56; Asingh and Lynnerup 2007, 17-19).

That the primary deposition took place while the peat cuts were still filled with water suggests that lowering into water constituted a central element in the ritual act. It has been proposed that the depositions were fertility offerings (Becker 1971;51) and that the surface of the water was a "gateway" or "portal" to the world of the gods (Kaul 2003, 19-22). We can only speculate as to the motives behind these depositions, but if immersion into water was significant, then these water-filled peat cuts were, in many places, the only local bodies of open water in the "lake-poor" landscape of the Iron Age.

The basal layer in the large, near-marginal peat cut A34 has been dated to $182 \pm 51$ cal B.C. Being located close to the edge of the bog, it was presumably one of the first peat cuts to be established, 
and a nearby oak trunk could have functioned as a walkway.

The age-depth model for peat cut A34 (Figure 5) shows that it held open water from $182 \pm 51 \mathrm{cal}$ B.C to $83 \pm 33$ cal B.C. The deposits that formed in it subsequently consist of peat mixed with gyttja, and it is conceivable that it was still possible to lower objects into water in the peat cut at this time too. Around cal A.D. 54 \pm 27 , a layer of peat developed across the bog and it was no longer possible to deposit vessels etc. It was also during this phase that the bog was abandoned and became colonised by willow scrub, which indicates that the bog had been abandoned as a ritual area. During the Early Iron Age, Fuglsøgaard Mose served several purposes; as a grazing and/or haymaking area, a peat extraction site, and a place for ritual depositions. While the first seems to continue through the Early Pre-Roman Iron Age until the Early Roman Iron Age, the peat extraction and ritual depositions belong to a relatively short period of maybe 100 years. It is not possible to determine, if the depositions started after the conclusion of the peat extraction phase or if they were at least partly simultaneous. One could imagine that depositions were made in parts of the bog, while peat extraction was still taking place in other parts. However, there seems to be some time lag between peat extraction and deposition, when one sees the gyttja layers formed before the first depositions.

\section{White/light-coloured stones}

Stones were found in many places in Fuglsøgaard Mose and varied in size from small pebbles to large stones weighing several kilograms. As stones do not occur naturally in peat deposits, they must be seen as an anthropogenic element. Most of them occur in association with the ritual depositions and must also have been part of the ritual activities. In some cases, the stones lay beneath the artefacts, in others either together with or above them (Figure 3 and supplementary data). Stones were also evident on the low baulk between the double peat cuts and on top of the overgrown peat cut, and some peat cuts only contained stones. It is possible that the stones were deposited together with organic material which has decayed without trace, but they may also have had a ritual value in themselves. The Secchi depth in the peat cuts, i. e. the depth at which the reflectance equals the intensity of light backscattered from the water, is unlikely to have been more than $20-30 \mathrm{~cm}$, which means that some of the high-up stones could possibly have been glimpsed in the peat cuts, while others had sunk into the darkness. It has previously been suggested that the peat cuts have been used for the retting of flax and that the stones could have been used to hold down the bundles of stems (Karg 2010). This possibility can, however, be discounted as neither pollen, macro-remains or other traces of flax have been found, apart from the bundles that clearly had been deposited as a part of the ritual activities (Figure 4). Moreover, there are examples of stones that appear to have been pressed into the peaty base or the baulk from the peat cut. Several of the vessels also contained stones, and these had been placed in the vessels prior to deposition. There were, as already mentioned, also smaller stones distributed up through the stratigraphy and scattered throughout the peat. The latter must be interpreted as having been thrown out onto the overgrown peat cuts from dry land. A parallel to the continued deposition of stones can be found in the "stone-throwing" or "sacrifice-throwing" which was widespread in Scandinavia up into modern times (Henningsen and Laursen 2006), or in present-day wishing wells.

The stones are predominantly white or light-coloured, and the colour combinations do not reflect the stones that are otherwise evident naturally in the area: There appears to have been an intentional selection of white or light-coloured stones. Stones associated with ritual depositions in bogs have been noted from a number of earlier archaeological excavations. Numerous stones were found associated with the Hjortspring, Nydam and Ejsbøl war booty deposits, both above and beneath the deposited artefacts: This is interpreted as a result of "bombardment" of the objects after deposition (Kaul 2003, 215; Christensen 2003, 346-254). Becker $(1971,17)$ also mentions several bog sites where stones were involved, and there are numerous other similar records (e.g. Ferdinand and Ferdinand 1961, 52-55; Lund 2002, 147). Despite this, the presence of these stones is only sparsely discussed in the literature, and the colour 
composition of the stones has been subject to professional discussion to an even lesser extent. One exception is Käringsjön in Scania (Arbmann 1954; Carlie 1998), where the presence of white stones is interpreted as a result of intentional selection and an integrated part of the ritual activities. Two of the present authors (M.F.M and C.C.) have, over a number of years, had the opportunity to investigate several contemporary bog sites with ritual depositions in various parts of Denmark, and the presence of white/light-coloured stones appears to be a characteristic feature at many of these. The type of stone appears to be of lesser significance, as examples were found of quartzite, quartz and patinated flint among the light-coloured stones.

Prehistoric peat cuts can often be extremely difficult to detect and identify in the field, as the deposits they contain frequently have the same appearance and structure as those of the surrounding bog. They are often not detected until late in the excavation, by which time valuable traces and deposits may have been dug away. It is therefore important to be aware at an early stage in archaeological and palaeoecological investigations of wetland areas of the significance of stones, especially white/light-coloured examples, which can reveal the presence of prehistoric peat cuts and potential ritual depositions. Due to the frequently massive occurrence of deposited stones, it has been possible in several cases to locate Iron Age peat cuts solely with the aid of a steel probe.

\section{Conclusion}

In the Late Bronze Age and Pre-Roman Iron Age, Fuglsøgaards Mose lay surrounded by an open and intensely exploited cultural landscape. Already before the peat cuts were established, the bog was open and presumably grazed. Around $180 \mathrm{cal}$ B.C., the first peat cuts were established, and it is estimated that between 250 and $500 \mathrm{~m}^{3}$ of peat was removed. After the peat had been extracted, the peat cuts were left as water-filled pits in the bog through a period of about a century. It was during this time that the primary deposition of objects in the peat cuts took place. As peat growth resumed, eventually filling the peat cuts, the open water disappeared, and the depositions decreased, i.e. there appears to have been a direct link between open water and the ritual depositions. An exception to this was, however, the white/light-coloured stones, which were found in association with the other ritually deposited objects but also continued to be deposited up until and shortly after the pit cuts had become overgrown with peat again. The bog consequently retained some form of ritual status during the centuries after the other depositions had ceased. During this period, up until the final growth of peat over the peat cuts around cal A.D. 50 , the bog was kept open, either by grazing or haymaking. Traces of activities in the bog then cease, and it is evident that the surface of the bog became colonised by willow scrub.

\section{Acknowledgments}

The authors would like to thank the three anonymous reviewers and Mogens Bo Henriksen for valuable comments on the manuscript. This work was part of the research project "Jernalderens offermoser" supported by the Danish Ministry of Culture grant FPK.2015-0068.

\section{References}

Aaby, B. 2008. Geologi og vegetation gennem 15.000 år. In: Boysen, F., Brøgger, N.P., Daugaard, B. og Ebbesen, A., eds. Bølling Sø og Stenholt Skov - Historie og natur. Ikast: Foreningen Forlagt Boelund, 6-9.

Aaby, B. and Vegger, P.B. 1995. Tykke muldlag fortæller om brug af tørvegødning. Arkeologiske udgravninger i Danmark 1996. Copenhagen: Det Arkæologiske Nævn, 30-35.

Andersen, S.T., Aaby, B. and Odgaard, B.V. 1983. Environment and Man. Current Studies in Vegeta- 
tional History at the Geological Survey of Denmark. Journal of Danish Archaeology, 2, 184-196. https://doi.org/10.1080/0108464x.1983.10589903

Andersen, A.G. 1993a. Et religiøst center i Båg herred - i perioden mellem sen førromersk jernalder og begyndelsen af yngre romersk jernalder. Fynske Minder, 65-89.

Andersen, A.G. 1993b. Frugtbarhedsofringer i Sydvestfyns ældre jernalder. KUML, 199-210.

Arbmann, H. 1954. Käringsjön. Studier I halländsk järnålder. KVHAA.s handlingar 59:1. Stockholm

Asingh, P. and Lynnerup. N. (ed) 2007. Grauballe Man, An Iron age Bog Body Revisited. Højbjerg: Jutland Archaeological Society Publications, 49.

Becker, C.J. 1948. Tørvegravning i ældre jernalder. Nationalmuseets Arbejdsmark, 92-100.

Becker, C.J. 1971. "Mosepotter” fra Danmarks jernalder. Aarbøger for Nordisk Oldkyndighed, 5-52.

Berglund, B. 2003. Human inpact and climate changes - synchronous events and a causal link? Quaternary International, 105, 7-12. https://doi.org/10.1016/s1040-6182(02)00144-1

Branigan, K., Edwards, K.J. and Merrony, C. 2002. Bronze Age fule: the oldest direct evidence for deep peat cutting and stack construction? Antiquity, 76, 849-855.

https://doi.org/10.1017/s0003598x0009133x

Bronk Ramsey, C. 2008. Deposition models for chronological records. Quaternary Science Reviews, 27 (1-2), 42-60. https://doi.org/10.1016/j.quascirev.2007.01.019

Bronk Ramsey, C. 2009. Bayesian analysis of radiocarbon dates. Radiocarbon, 51, 337-360. https://doi.org/10.1017/s0033822200033865

Carlie, A. 1998. Käringsjön. A fertility sacrificial site from the Late Roman Iron Age in South-west Sweden. Current Swedish Archaeology, 6, 17-37.

Christensen. C. 2003. Jernalderens offermoser. In: Jørgensen, L., Storgaard, B. og Thomsen, L.G., eds. Sejrens Triumf - Norden i skyggen af det romerske Imperium. Nationalmuseet, 346-354.

Christensen, C. 2020. Geological and palaeoecological investigations at Nydam. In: Holst, S. and Nielsen, P.O., eds. Excavating Nydam. Archaeology, Palaeoecology and Preservation. The National Museum's Research Project 1989-99. Copenhagen: Det Kongelige Nordiske Oldskriftselskab, Nordiske Fortidsminder, Serie B, vol.33, 303-336.

Christensen, C. and Fiedel, R. 2003. Tørvegravning i forhistorisk tid. Nationalmuseets Arbejdsmark, 85-99.

Christensen, C. and Mortensen, M.F. 2011. Danmark fra istid til fremtid - med fokus på markante klimasving. Geologisk Nyt, 3, 28-32.

Christensen, C., Sørensen, I. and Mortensen, M.F. 2012. Der eisenzeitliche Opfersee in Ejsbøl. Geobotanische Untersuchungen in den Jahren 1956-1964, 1967 und 1999. In: Jørgensen, A.N. und Ander- 
sen, H.C.H., eds. Ejsbøl Mose - Die Kriegsbeuteoppfer im Moor von Ejsbøl aus dem späten 1.Jh. v.Chr. bis zum frühen 5.Jh. n.Chr. Højbjerg: Jutland Archaeological Society Publications, 80, 312-323.

Ferdinand, J. and Ferdinand, K. 1961. Jernalderofferfund i Valmose ved Rislev. KUML, 47-90.

Fiedel, R. 2003. Om moser og mosefund. Kulturhistorisk Museum Randers, Årbog, 65-80.

Fischer, C. 1980. Moseligene fra Bjældskovdal. KUML, 7-44.

Fischer, C. 2007. Tollundmanden. Gaven til guderne. Mosefund fra Danmarks forhistorie. Hovedland.

Fægri, K. and Iversen, J., 1989. Textbook of pollen analysis. London: John Wiley.

van Geel B. and Renssen H. 1998. Abrupt climate change around 2,650 BP in North-West Europe: evidence for climatic teleconnections and a tentative explanation. In: A. S. Issar, N. Brown, eds. Water, Environment and Society in Times of Climatic Change. Springer 21-41.

https://doi.org/10.1007/978-94-017-3659-6_2

Gotfredsen, A.B. 2004. Knoglemateriale fra Fuglsøgård Mose, KHM 1400 Z.M.K. 16/2004, en offermose fra førromersk jernalder, Udbyneder sogn. Report from the Zoological Museum, University of Copenhagen.

Henningsen, G. and Laursen, J. 2006. Stenkast. KUML, 243-278.

Henriksen, M.B. 2016. Bålets betydning. Ligbranding i Danmarks oldtid belyst ved arkaologiske fund og ligbrendingseksperimenter. $\mathrm{PhD}$ dissertation. University of Copenhagen, Faculty of the Humanities, Saxo-institute.

Henriksen, P.S. 2001. Arkaobotanisk undersøgelse af materiale fra aldre bronzealder fra Legärd, Thy. NNU-rapport 29.

Henriksen, P. S., Harild, J. A. and Jensen, P. M. 2009. De arkæobotaniske analyser af materialet fra Nr. Hedegård. In: M. Runge, eds. Nørre Hedegård. En nordjysk byhøj fra aldre jernalder. Højbjerg: Jutland Archaeological Society Publications, 66, 247-252.

Henriksen, P.S., Robinson, D.E and Kelertas, K. 2018. Bronze Age agriculture, land use and vegetation at Bjerre Enge based on archaebotanical analyses. In: J.H. Bech, B.V. Eriksen and K. Kristiansen, eds. Bronze Age Settlement Structure and land Use in Thy, Northwest Denmark. Højbjerg: Jutland Archaeological Society Publications, 102, 385-449.

Henriksen, P. S. and Harild, J. A. 2020. Early Iron Age agriculture and land use in Thy. In: Smedegard: A village mound from the Early Iron Age near Nors in Thy, north-west Denmark. Copenhagen: Det Kongelige Nordiske Oldskriftselskab, Nordiske fortidsminder, Serie B, Vol. 30., 537-572.

Hove, Th.,Th. 1983. Tørvegravning i Danmark: fra håndgravning til moseindustri: udvikling og vilkår. Herning: Poul Kristensens Forlag.

Ilkjær, J. 1994. Illerup Ådal. Mosefundenes kronologi og proveniens. Et resume. Højbjerg: Jutland Archaeological Society. 
Ilkjær, J. 2008. Die Funde aus Illerup Ådal - der Stand der Forschung im Jahr 2006. In: A. Abegg-Wigg und A. Rau, eds. Aktuelle Forschungen zu Kriegsbeuteopfern und Fürstegräbern im Barbaricum. Schleswig: Schriften des Archäologischen Landesmuseums Band 4, 19-24.

Jensen, C.K. 2005. Kontekstuel Kronologi - en revision af det kronologiske grundlag for forromersk jernalder i Sydskandinavien. Højbjerg: Lag 7.

Johannesen, K. 2016. Rituals of Common Things: The ritual and religion of the mixed wetland deposits in the early Iron Age of Southern Scandinavia. Ph.D. dissertation. Museum Østjylland and Aarhus University.

Jørgensen, A.N. and Andersen, H.C.H. 2012. Ejsbøl Mose - Die Kriegsbeuteopfer im Moor von Ejsbøl aus dem späten 1.Jh. v.Chr. bis zum frühen 5.Jh. n.Chr. Højbjerg: Jutland Archaeological Society Publications, 80 .

Jørgensen, S. 1956. Grauballemandens fundsted - en mosegeologisk undersøgelse. KUML, 114-130.

Karg, S. 2010. Seltsame Gruben in einem Feuchtgebiet in Jütland, Dänemark. Nachtrichtenblatt Arbeitskreis Unterwasserarchäologie, Band 10, 37-40.

Kaul, F. 1991. Gundestrupkedlen. Baggrund og billedverden. Copenhagen: Nationalmuseet. Nyt Nordisk Forlag Arnold Busck.

Kaul, F. 2003. Mosen - porten til den anden verden. In: In: Jørgensen, L., Storgaard, B. og Thomsen, L.G. Sejrens Triumf - Norden i skyggen af det romerske Imperium. Copenhagen: Nationalmuseet, 18-43.

Kolstrup, E. 2009. Vegetation and environment in Nydam, Denmark, during the Iron Age. Jernalderen I Nordeuropa. Carlsbergfondet, Nationalmuseet and Moesgaard Museum. Højbjerg: Jutland Archaeological Society Publications, 65. Højbjerg.

Lerche, G. 1985. Wooden T-Shaped Spades and Double Paddle-Spades. In: K. Kristiansen (ed.). Archaeological formation processes. The representativity of archaeological remains from Danish Prehistory. Copenhagen: Nationalmuseet, 207-214.

Lund, J. 2002. Forlev Nymølle - En offerplads fra yngre forromersk jernalder. KUML, 143-195.

Lyngstrøm, H. 2008. Dansk Jern - en kulturhistorisk analyse af fremstilling, fordeling og forbrug. Nordiske Fortidsminder. Serie C, bind 5. Copenhagen: Det Kongelig Nordiske Oldskriftselskab.

Lyngstrøm, H. 2016. T-formede træspader - form og funktion. Midtjyske fortellinger - Årbog for Museum Midtjylland, 101-112.

Mandrup, P., Lundby, P. and Laursen, K. 2017. FHM 5478, Lauritshøj II. Udgravningsberetning Moesgaard Museum.

Mikkelsen, P.H. 2004. KHM 1400. Fuglsøgård Mose - vedbestemmelse aftra fra KHM 1400 (FHM4296/85). Moesgaard Museum. Konservering og naturvidenskabelig afdeling. Nr. 7. 
Moore, P.D., Webb, J.A., Collinson, M.E. 1991. Pollen Analysis. Oxford: Blackwell Scientific Publishers.

Mortensen, M.F., Birks, H.H., Christensen, C., Holm, J., Noe-Nygaard, N., Odgaard, B.V., Olsen, J. and Rasmussen, K.L. 2011. Late-glacial vegetation development in Denmark - new evidence based on macrofossils and pollen from Slotseng, a small-scale site in southern Jutland. Quaternary Sciences Reviews, 30, 2534-3550. https://doi.org/10.1016/j.quascirev.2011.04.018

Mortensen, M.F., Henriksen, P.S., Christensen, C., Petersen, P.V. and Olsen, J. 2014. Vegetation development in southeast Denmark during the Weichselian late Glacial - palaeoenvironmental studies close to the Palaeolithic site of Hasselø. Danish Journal of Archaeology, 3 (1), 48-66.

https://doi.org/10.1080/21662282.2014.994281

Odgaard, B. 2006. Fra bondestenalder til nutid. In: Sand-Jensen, K. og Larsen, G., eds. Naturen i Danmark - Geologien. København: Gyldendal, 333-359.

Odgaard, B. and Nielsen, A.B. 2009. Udvikling i arealdækning I perioden 0-1850. Pollen og landskabshistorie. In: Odgaard, B. and Rømer, J.R., eds. Danske landbrugslandskaber gennem 2000 år. Fra digevoldinger til støtteordninger. Aarhus: Aarhus Universitetsforlag, 41-58.

Olsen, J., Tikhomirov, D.,Grosen, C., Heinemeier, J. and Klein, M. 2016. Radiocarbon Analysis on the New AARAMS 1MV Tandetron. Radiocarbon, 1-9. https://doi.org/10.1017/rdc.2016.85

Olsen, A-L. H. og J-H. Bech 1995. Bålfærd. Skalk, 5, 11-15.

Olsen, A.-L. H., Bech, J.-H. Andersen, S.T., Bennike, P. Christensen, K. and Robinson, D.E. 1996. Damsgård. En overpløjet høj fra ældre bronzealder periode III med stenkiste og ligbrændingsgrube. KUML, 155-198.

Pantmann, P. 2017. Vådbundsundersøgelser. Arkæologiske strategier - Ældre jernalder.

https://slks.dk/fortidsminder-diger/arkaeologi-paa-land/museernes-arkaeologiske-arbejde/arkaeologiske-strategier/arkaeologiske-strategier/aeldre-jernalder/vaadbundsundersoegelser/ (accessed September 2019)

Petersen, H. 1888. Vognfundene i Dejbjerg Prestegaardsmose ved Ringkjøbing 1881 og 1883. Copenhagen: Det Kongelige Nordiske Oldskriftselskab, Nordiske Fortidsminder.

Rau, A. 2010. Nydam Mose: Die persongebundenen Gegenstände. Grabungen 1989-1999. Bd. 1 und 2. Jernalderen i Nordeuropa. Carlsbergfondet, Nationalmuseet und Moesgård Museum. Jutland Archaeological Society Publications, 72.

Reimer, P. J., E. Bard, A. Bayliss, J. W. Beck, P. G. Blackwell, C. Bronk Ramsey, C. E. Buck, H. Cheng, R. L. Edwards, M. Friedrich, P. M. Grootes, T. P. Guilderson, H. Haflidason, I. Hajdas, C. Hatté, T. J. Heaton, D. L. Hoffmann, A. G. Hogg, K. A. Hughen, K. F. Kaiser, B. Kromer, S. W. Manning, M. Niu, R. W. Reimer, D. A. Richards, E. M. Scott, J. R. Southon, R. A. Staff, C. S. M. Turney and J. van der Plicht. 2013. IntCal13 and Marine13 Radiocarbon Age Calibration Curves 0-50,000 Years cal BP. Radiocarbon 55(4), 1869-1887. https://doi.org/10.2458/azu_js_rc.55.16947 
Rieck, F. 2013. Over sø og land - ofrede skibe og våben i Nydam mose: udgivet i anledning af 150-året for fundet af Nydambåden. Museum Sønderjylland, Vikingeskibsmuseet, Nationalmuseet og Selskabet for Nydamforskning.

Rieck, F. 2014. Nydam Mose: Die Schiffe. Bind 3. Jernalderen I Nordeuropa. Jysk Arkæologisk Selskabs Skrifter, 72.

Robinson, D.E. 1994. Dyrkede planter fra Danmarks forhistorie. Arkæologiske udgravninger i Danmark 1993. Copenhagen: Det Arkæologiske Nævn, 20-39.

Rosenberg, G. 1937. Hjortspringfundet. Nordiske Fortidsminder III, 1. Copenhagen: Det Kongelige Nordiske Oldskriftselskab.

Schou, J.C., Moeslund, B., Båstrup-Spohr, L. og Sand-Jensen, K. 2017. Danmarks Vandplanter. BFNs forlag Nors.

Skousen, H. 2008. Arkaologi i lange baner. Forlaget Moesgaard. Moesgaard Museum.

Sugita, S. 1994. Pollen representation and vegetation in Quaternary sediments: Theory and method in patchy vegetation. Journal of Ecology, 82, 881-897. https://doi.org/10.2307/2261452

Svendsen, J. 2009. Tørvene triller. Mystik, mennesker og maskiner i mosen. DialogForum.

Søgaard, K., Christensen, C. and Mortensen, M.F. 2018. Pollen analysis from lake, field and beach-ridge deposits in the vicinity of the Bronze Age settlement at Bjerre Enge, Thy. In: Bech, J-H., Eriksen, B.V. and Kristiansen, K., eds. Bronze Age Settlement and Land-Use in Thy Northwest Denmark vol.1. Højbjerg: Jutland Archaeological Society Publications, 102, 193-222.

Troels-Smith, J. 1955. Characterization of unconsolidated sediments. Danmarks Geologiske Undersøgelser, Række IV, Bind 3, (10) 1-73.

Troels-Smith, J. 1961. De geologisk-botaniske forhold i forbindelse med Rislev-fundet. En foreløbig meddelelse. KUML, 90-96.

Ørsnes, M. 1988. Ejsbøl I. Waffenopferfunde des 4.-5. Jahrh. nach Chr. Copenhagen: Det Kongelige Nordiske Oldskriftselskab. Nordiske Fortidsminder, Serie B, vol. 11. 


\section{Supplementary material}

Percentage pollen diagram from sample column 4 showing selected taxa. The diagram shows the regrowth of peat in a peat cut. The pollen percentages have been calculated on the basis of the terrestrial taxa. The shaded area shows a $x 10$ exaggeration of the percentage values.

See also: Supplementary Material 1-2.
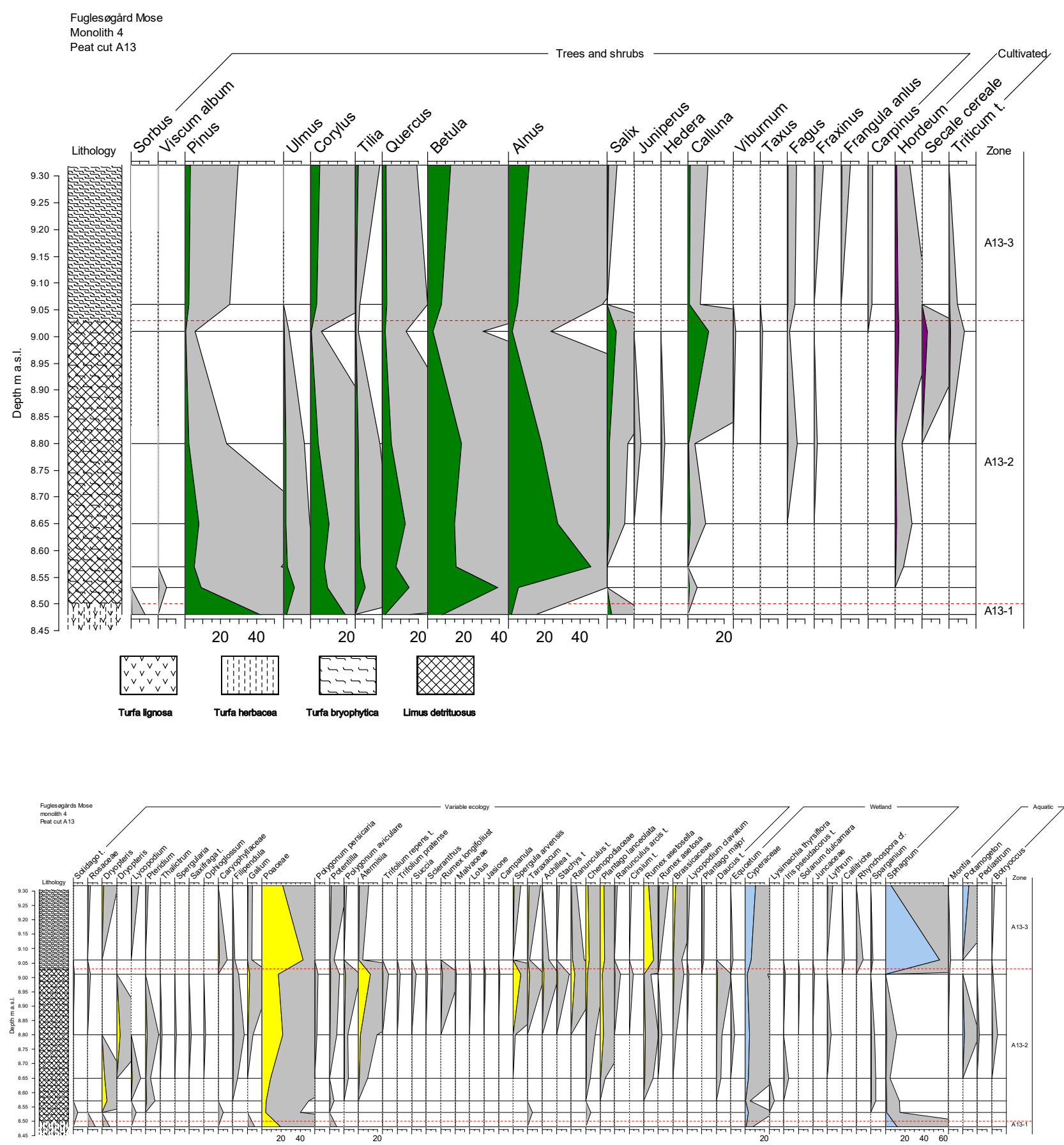


\section{Supplementary material}

Plan: R. Stidsing, Excavation photos: R. Fiedel.

See also: Supplementary Material 3.

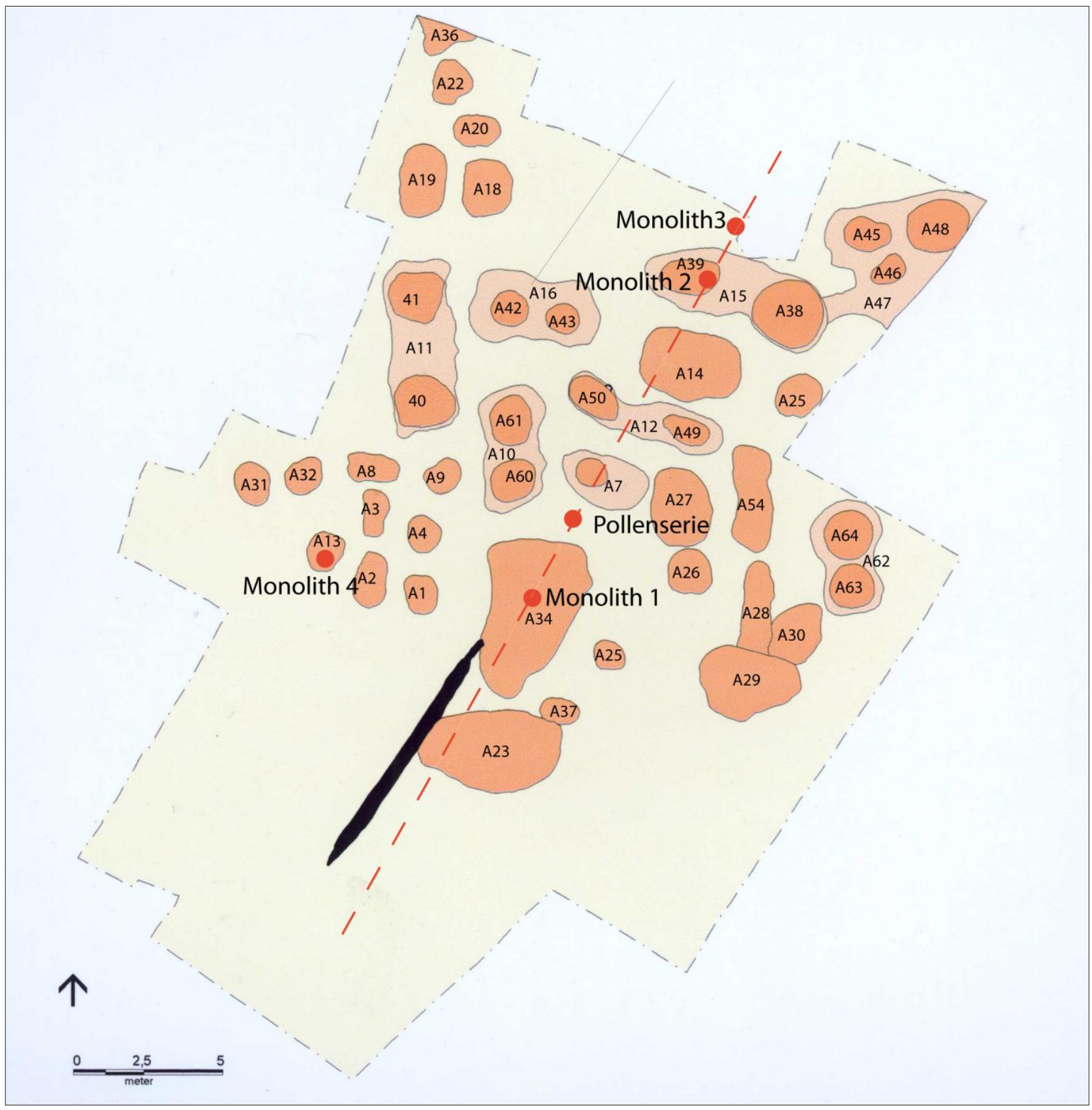

1. Plan of the central part of Fuglsøgård Mose. 


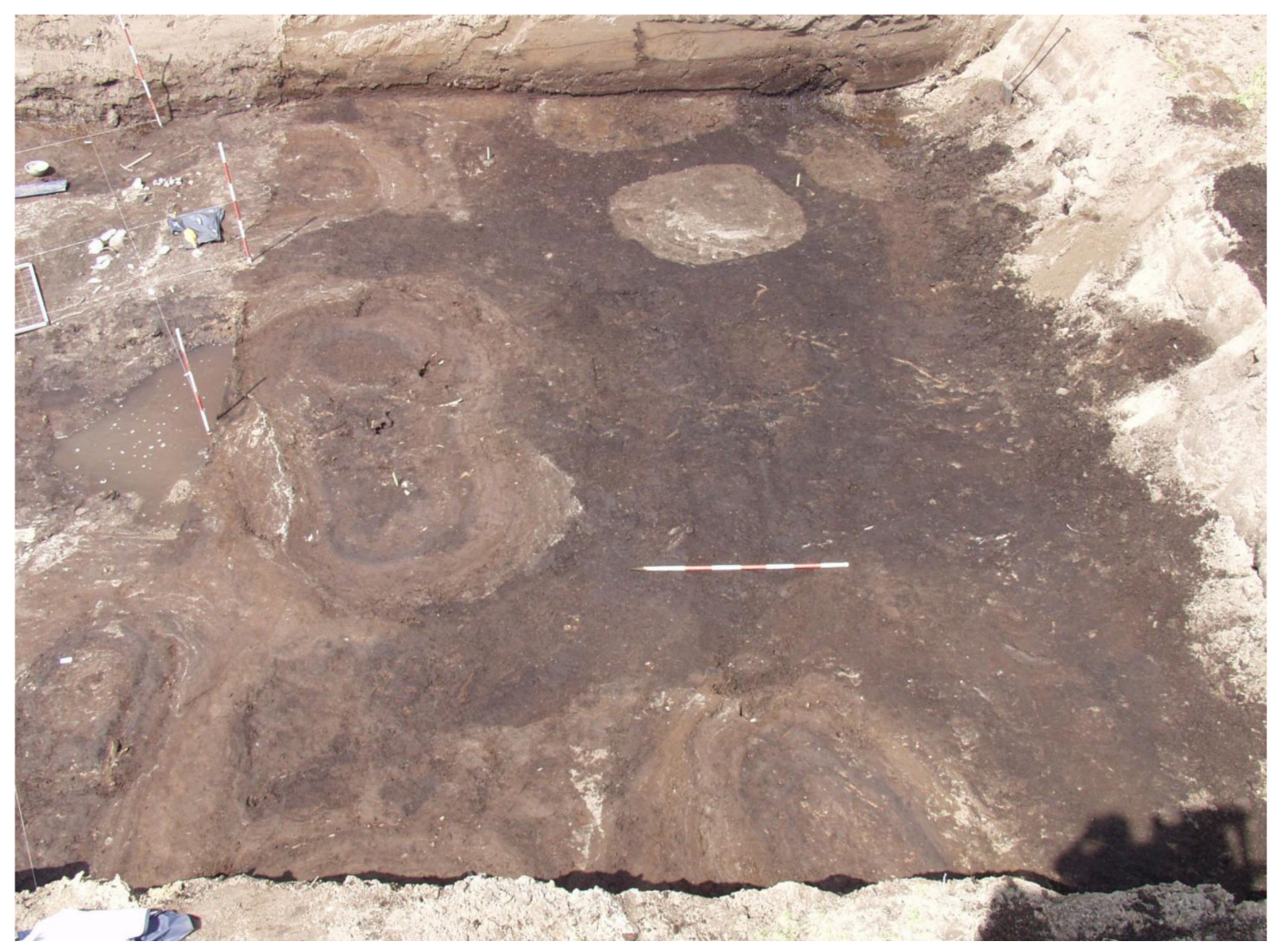

2. The western area, where the peat cuts are evident as pale "islands" in the dark wood peat. A newly-cleaned surface can be seen to the right. The surface to the left of the ranging rods had been cleaned a day earlier and the colours are already beginning to fade.

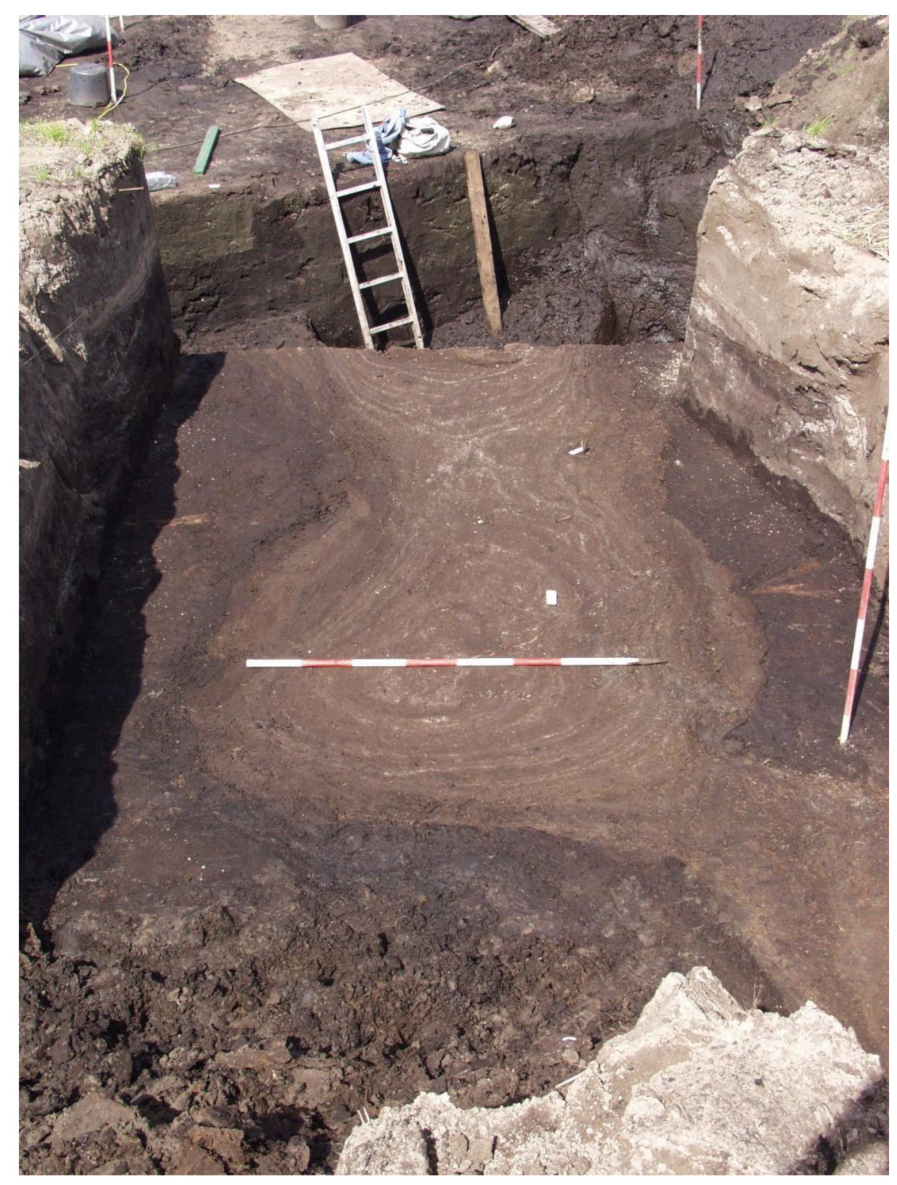

3. Double peat cut $\mathrm{A} 38$ and $\mathrm{A} 39$, with a connection to $\mathrm{A} 47$ on the lower right. 


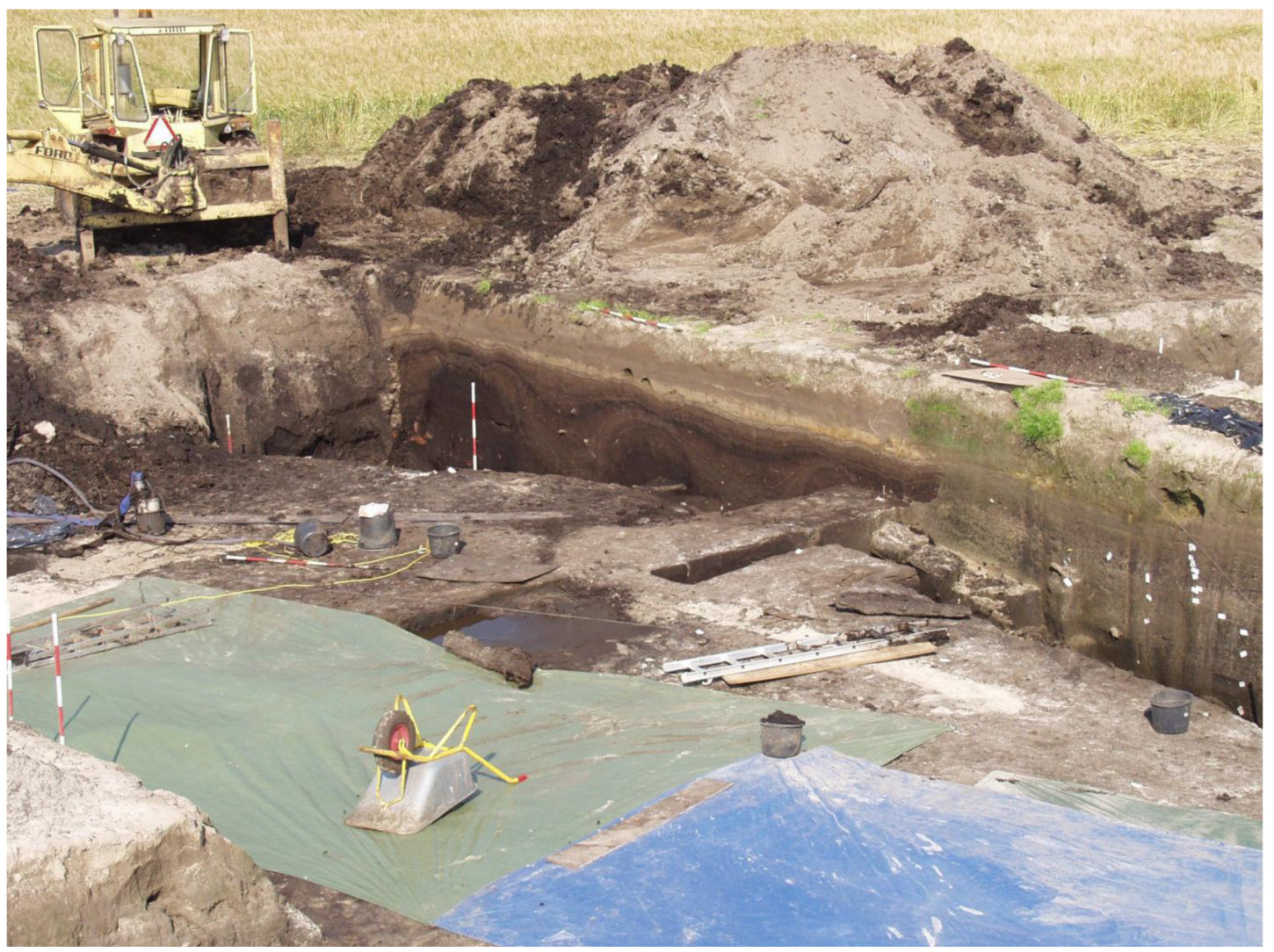

4. The excavation trench in summer 2002. Peat cuts A14 and A15 are evident in the background and the layers of peat which developed over the bog can be clearly seen.

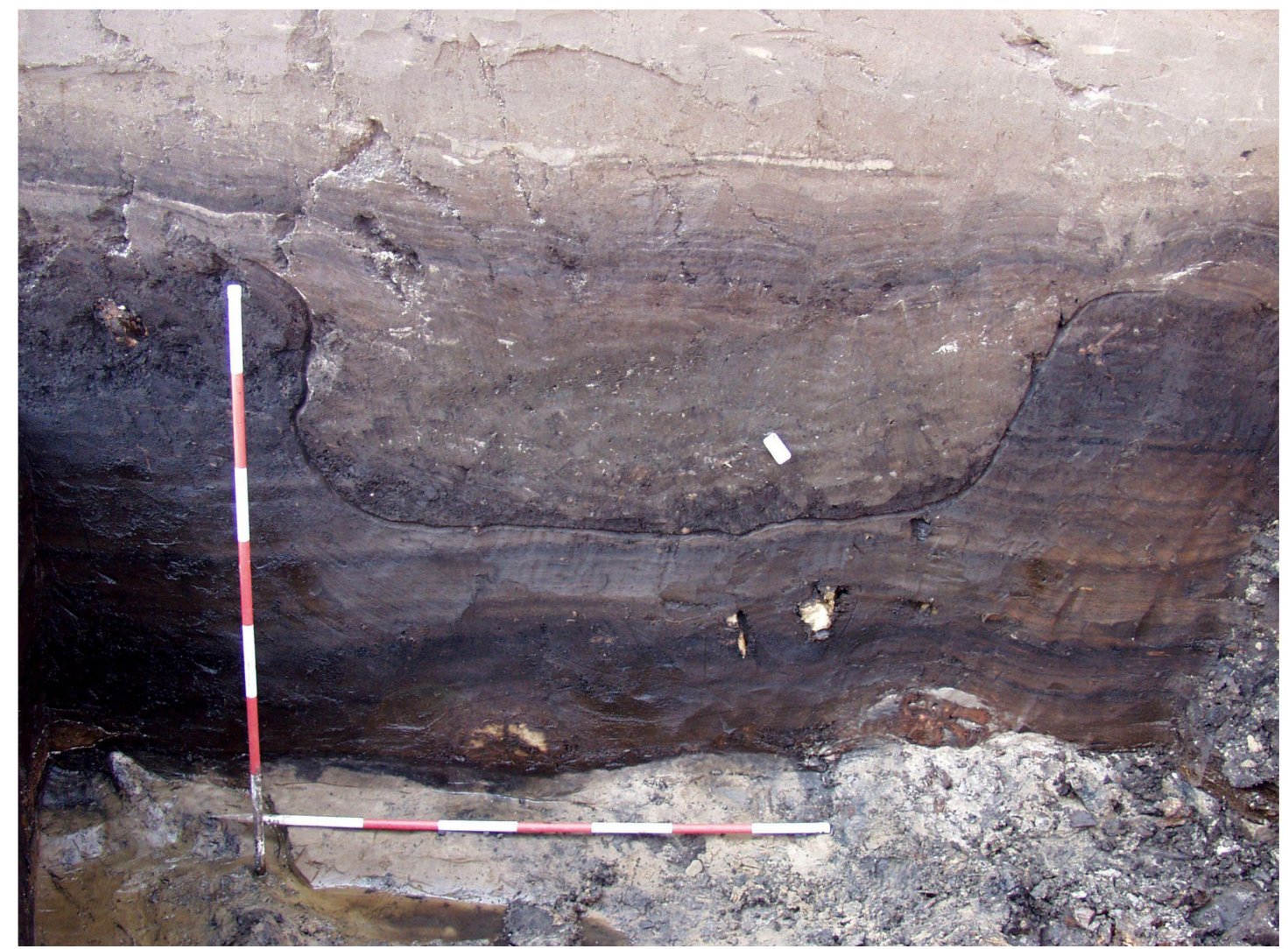

5. Section through peat cut A22. 

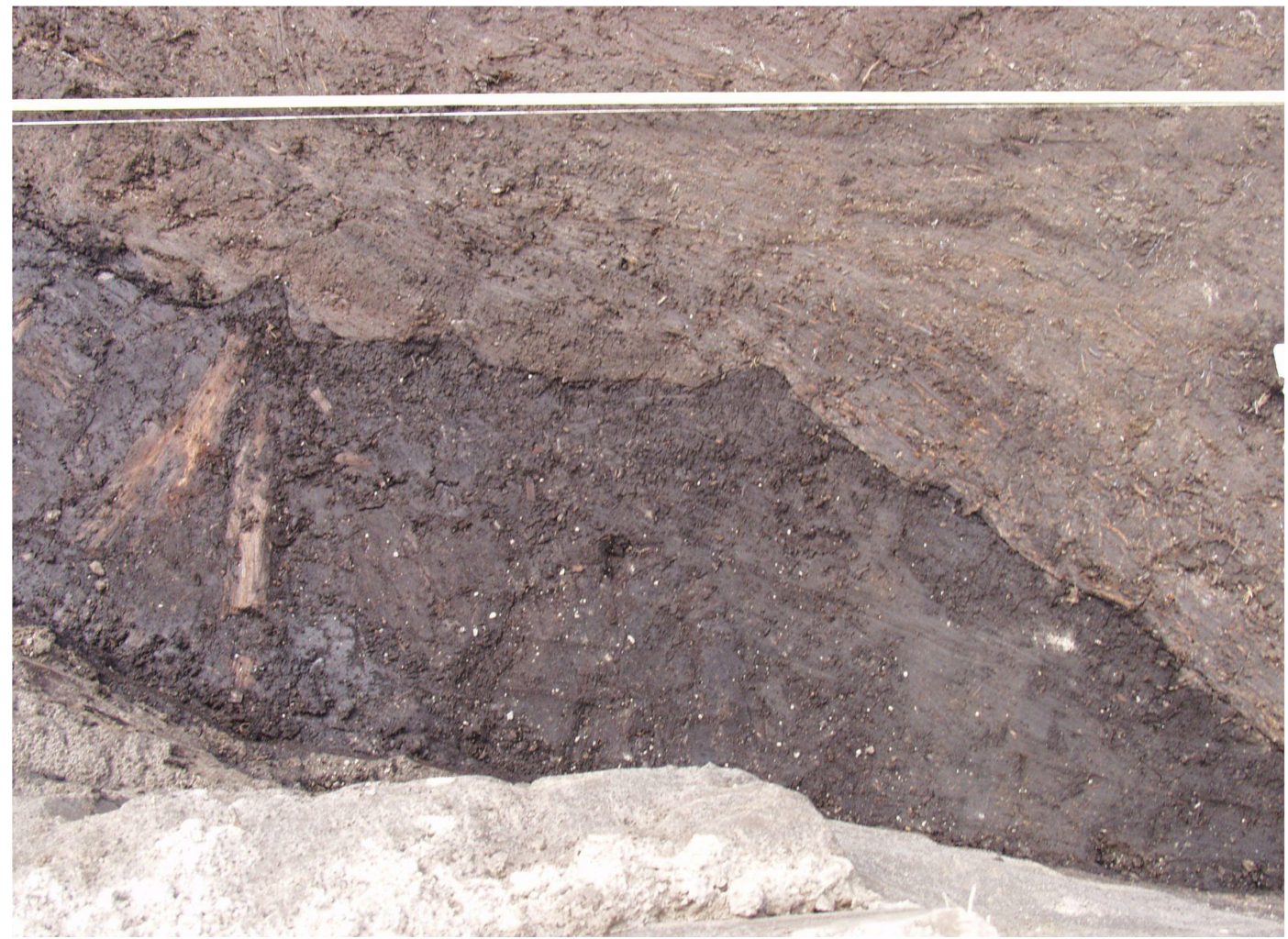

6. Edge of peat cut A23 with obvious spade marks between the dark wood peat and the paler later peat.

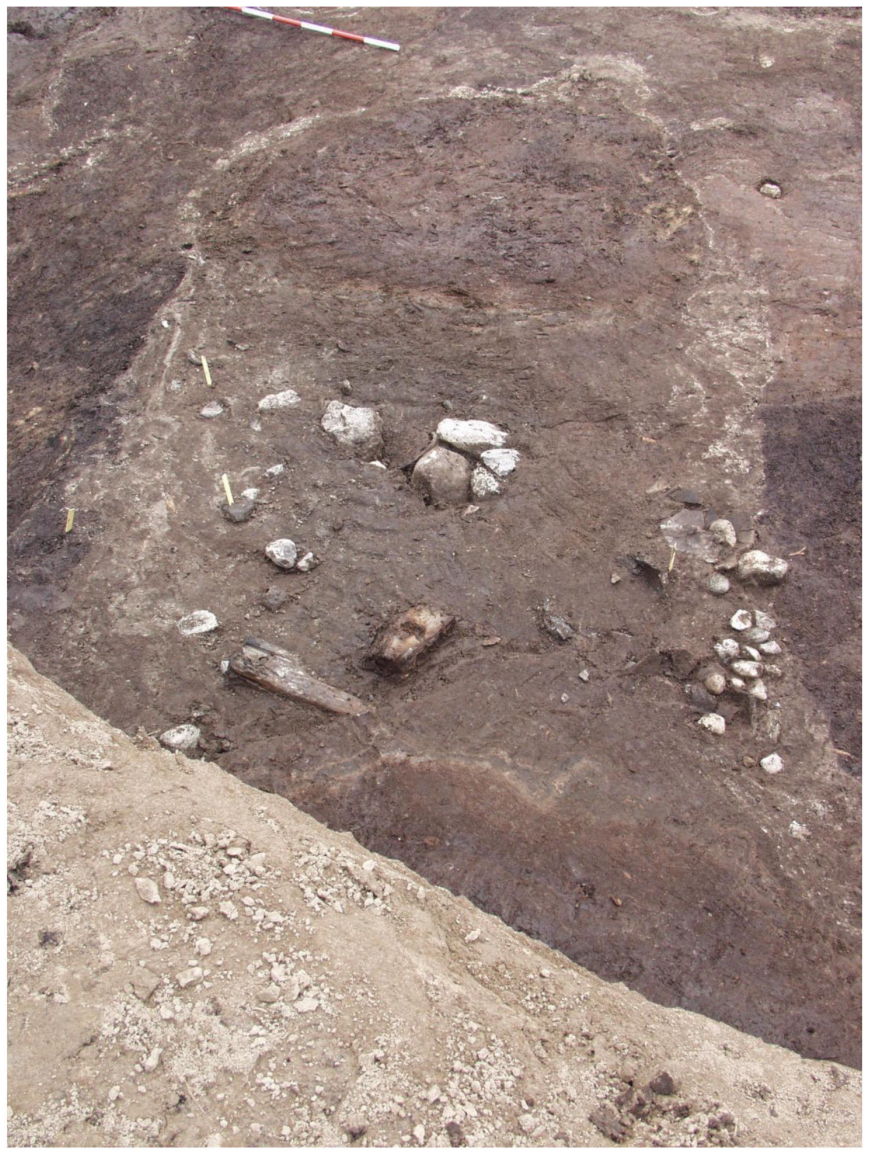

7. Depositions in area A11, between peat cut $A 40$ (back) and A41(front). Peat cut A40 is seen most clearly, while peat cut A41 is only partially exposed. the area between the two peat cuts, stones and votive artefacts can be seen resting on the intervening peat baulk. A total of six horse skulls had been deposited in these two peat cuts and the intervening pit. 


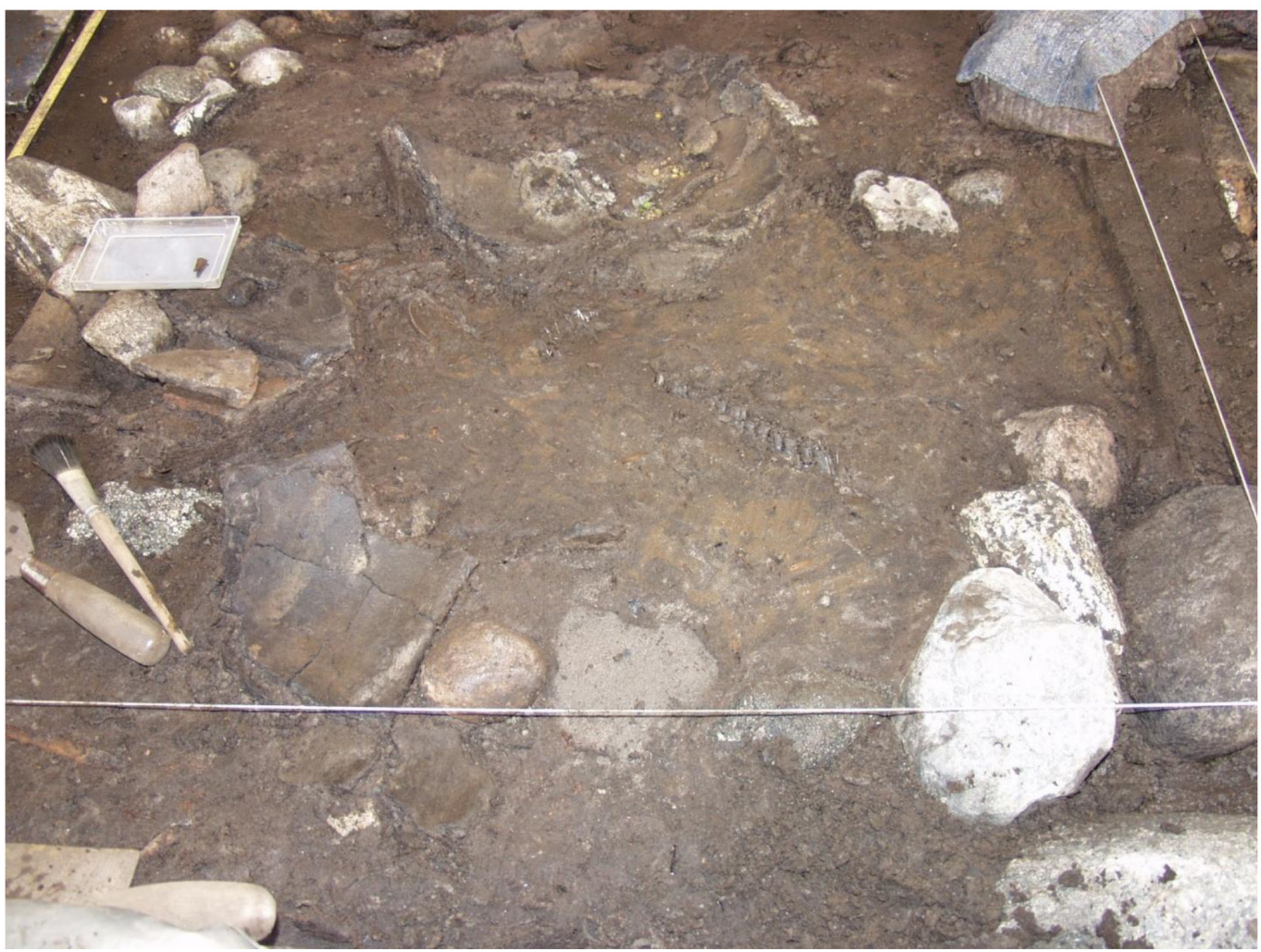

8. The skulls of six horses had been deposited in votive complex A11 consisting of the two peat cuts A40 and A41 and the intervening pit. Pottery vessels, wooden artefacts and stone had been placed around the skulls. This is interpreted as a coeval deposition. The preservation of bone in the bog is generally very poor and the skulls could only be very weakly perceived.

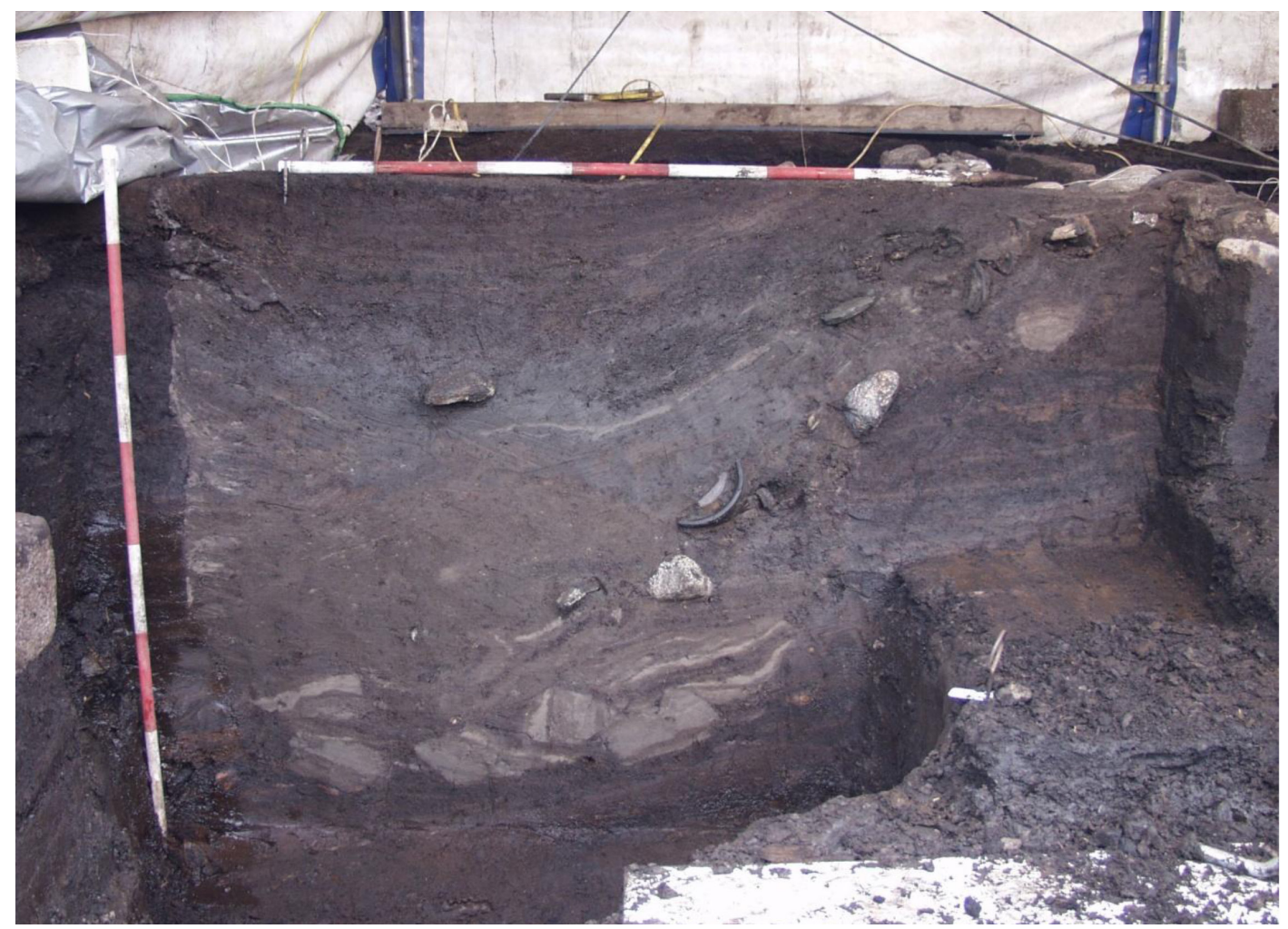

9. This peat cut (A40) is the southernmost of the two peat cuts below votive area A11. The pale sandy peats show that this peat cut was dug first, because they come from peat cut (A41), located directly to the north, which was dug later. Votive feature A11 is at the top of the excavation to the right, and stone and deposited artefacts have slipped down towards the base of the peat cut. 


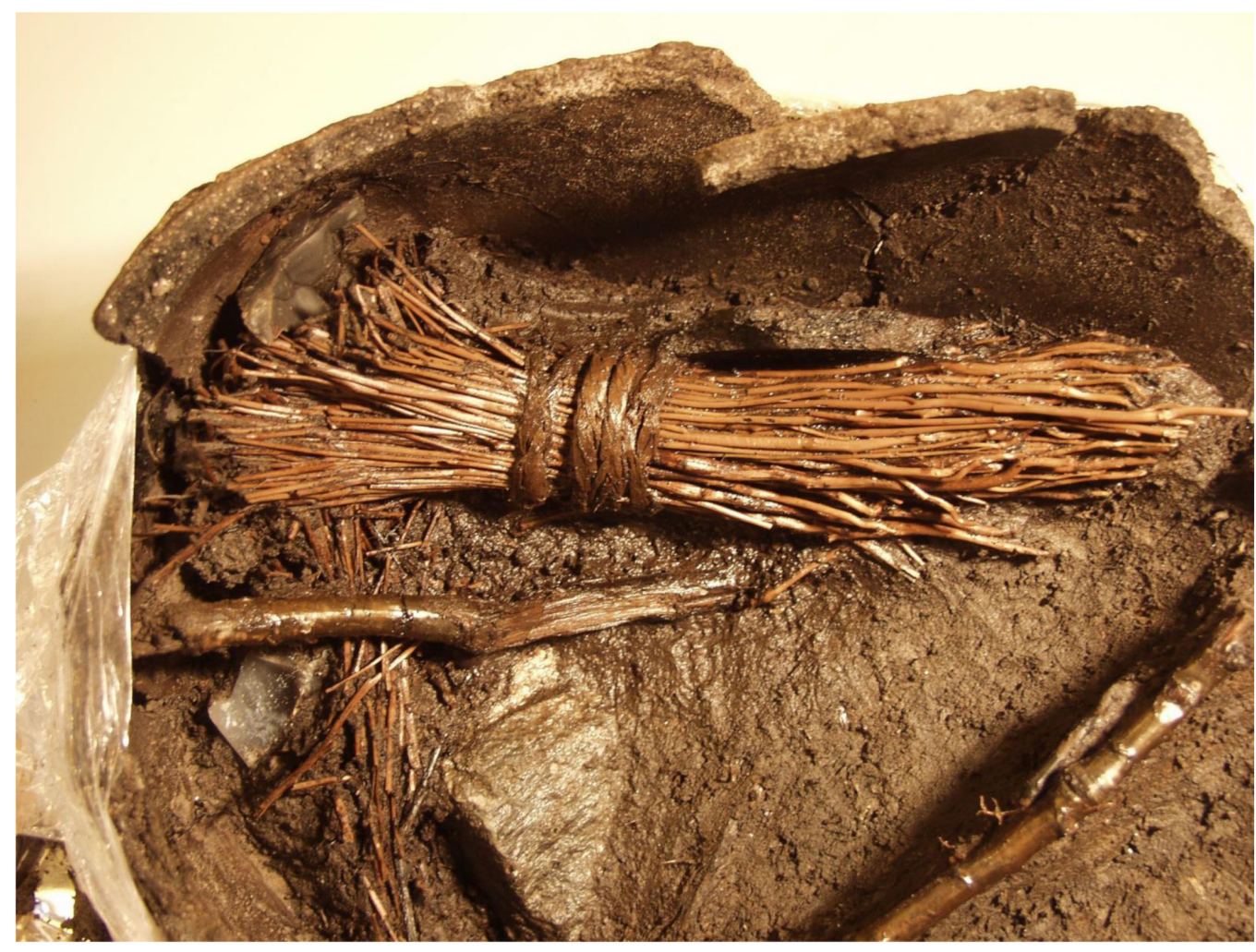

10. Pottery vessel $x-534$ from peat cut $A 40$, containing a small bundle of Linum usitatissimum (common flax). The flax bundle has been ${ }^{14} \mathrm{C}$ dated $1990 \pm 65$ (180 BC - AD 136).

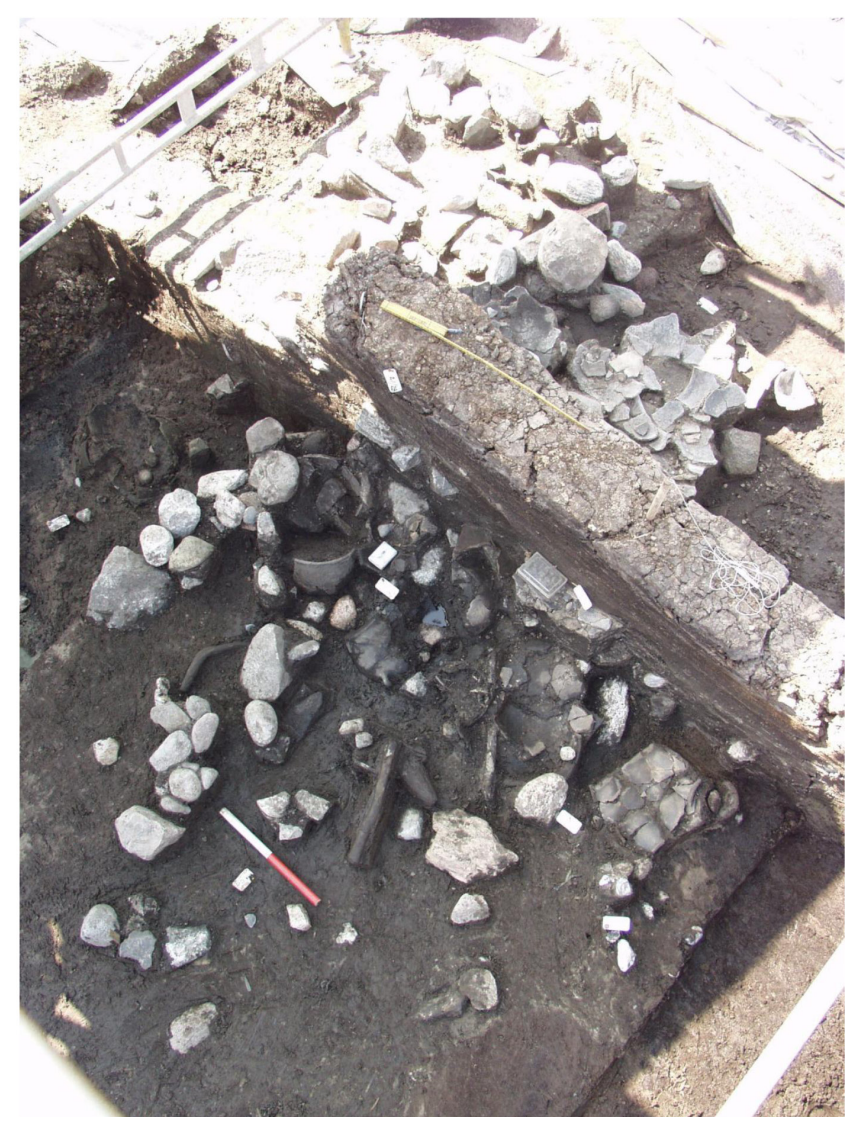

11. Peat cut A23, located close to the edge of the bog, was one of the richest in finds. It contained pottery vessels, wooden artefacts and many light-coloured stones. Unlike the others, this peat cut had been used for numerous depositions. 


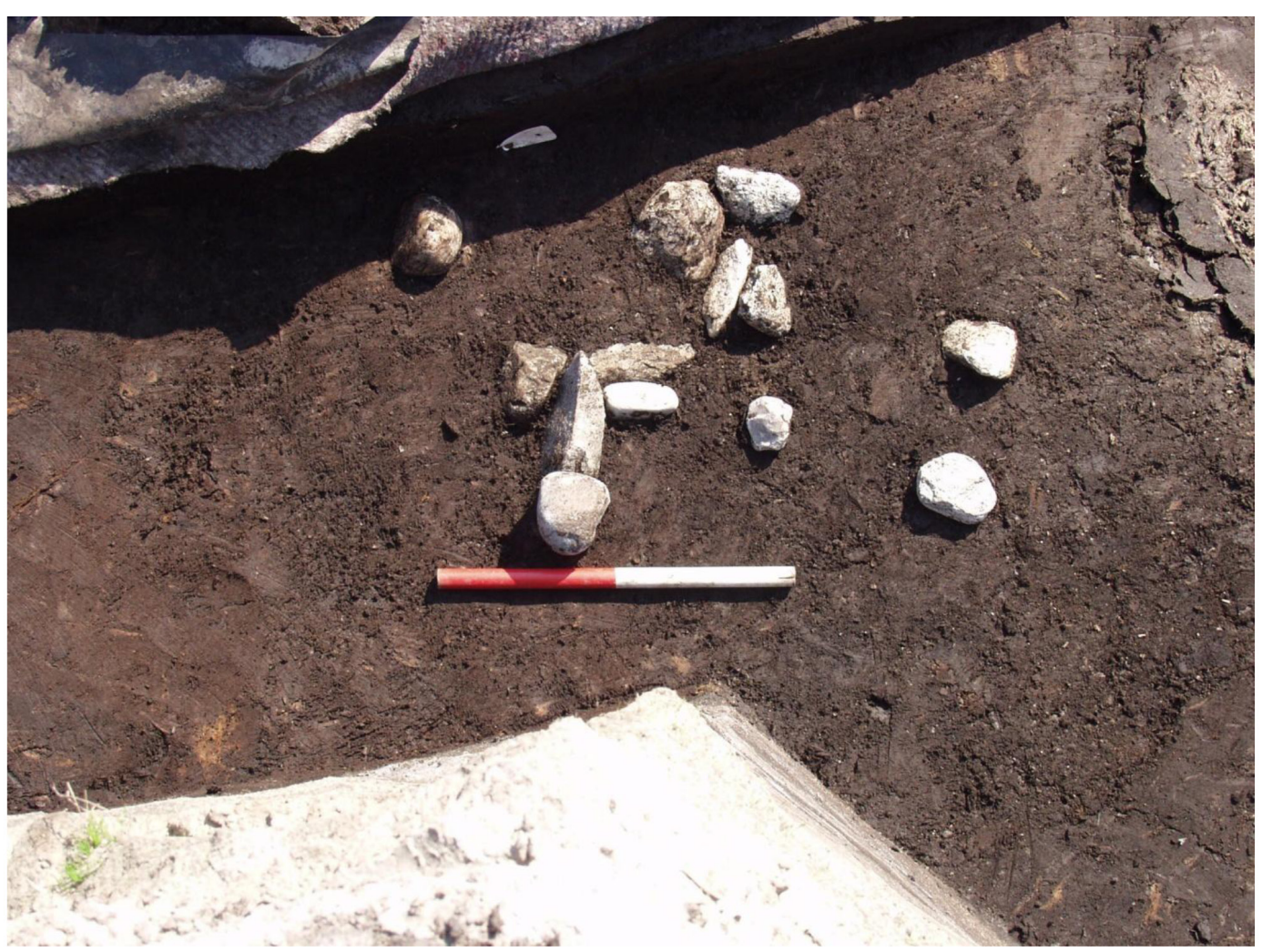

12. Deposition of white/light-coloured stones.

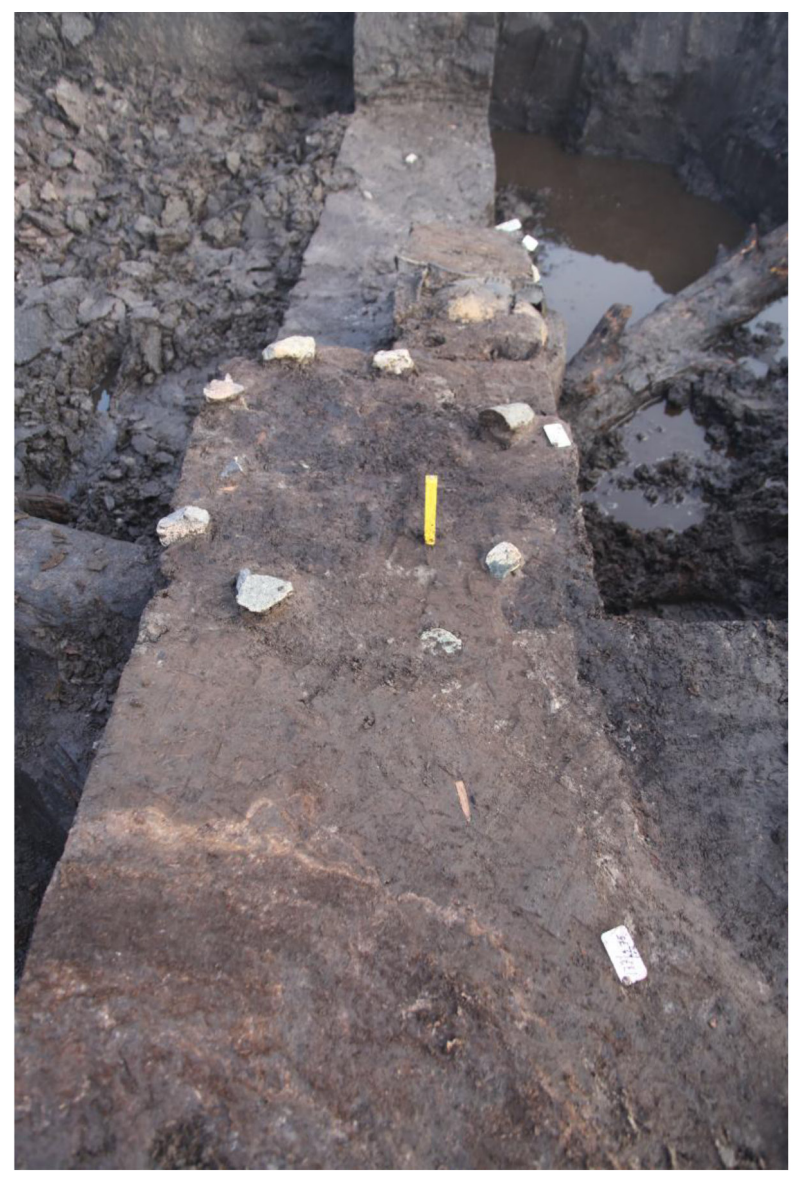

13. Light-coloured stones arranged in a circle on the peat baulk between peat cuts $A 121 S$ and A121N, which forms part of the votive area. 


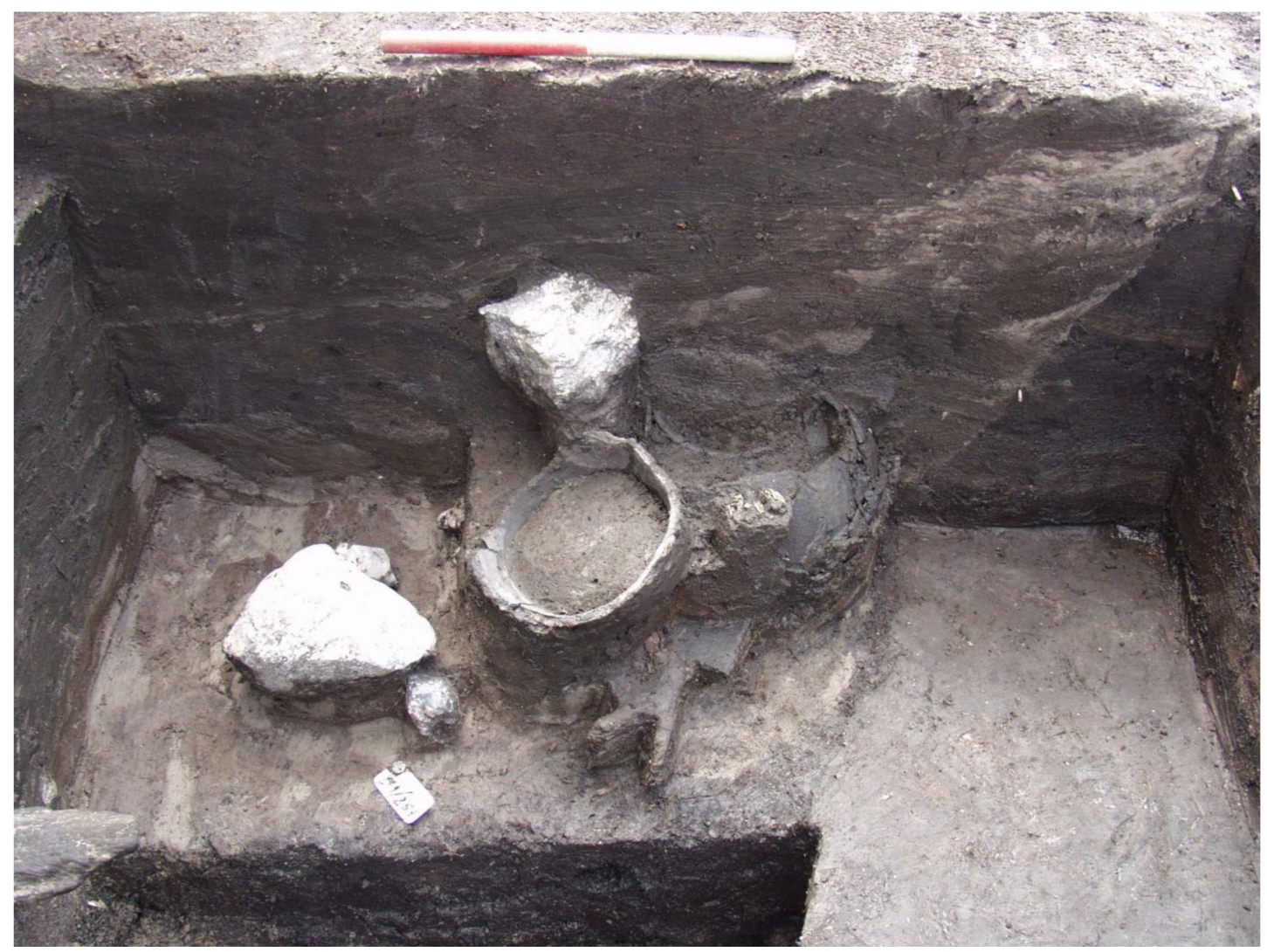

14. Deposition of pottery vessel, wood and stones in peat cut A34.

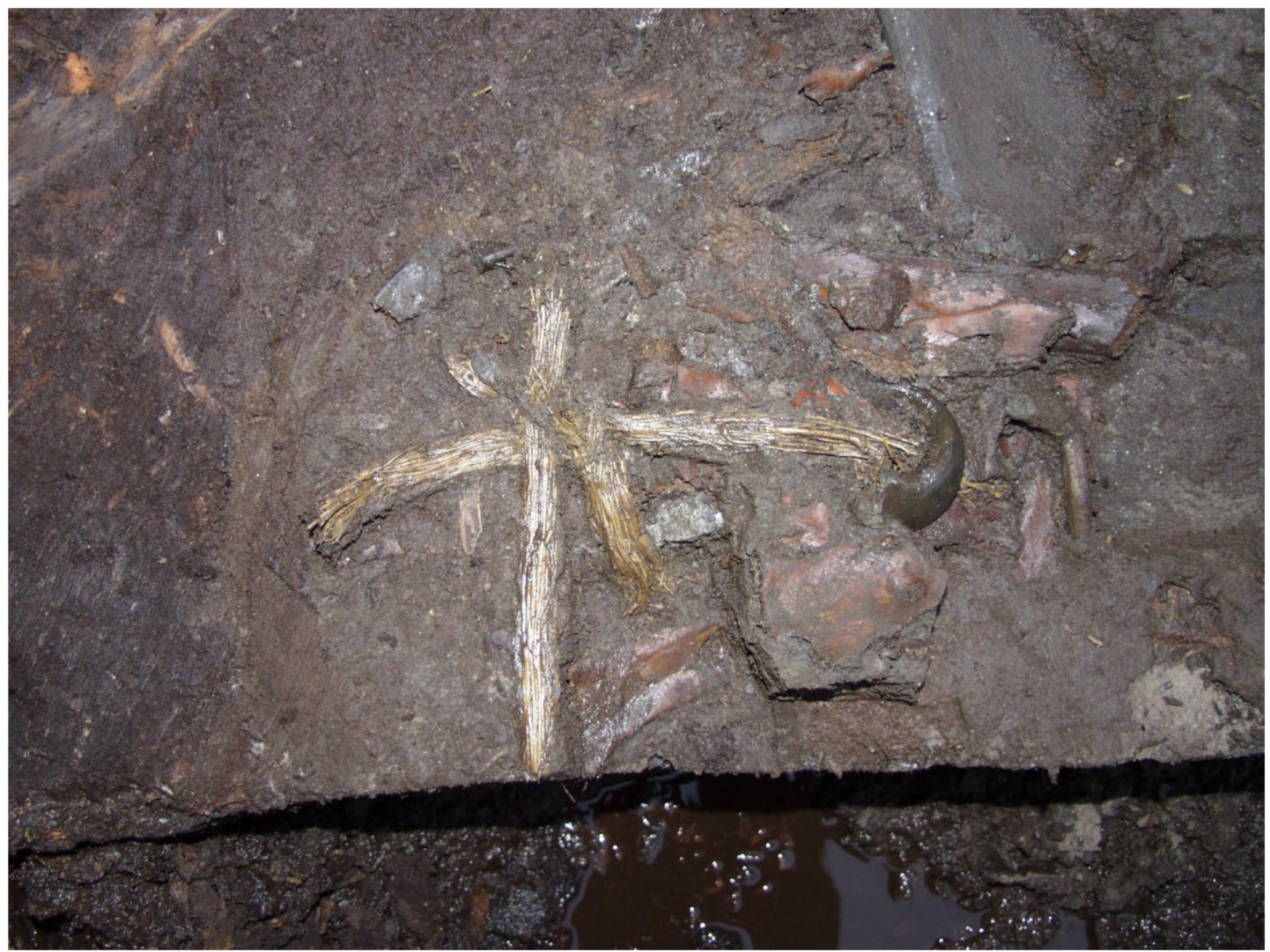

15. Bundles of Linum usitatissimum (common flax) placed at the base of peat cut A60. 